\title{
Breadwinning Patterns and Family Exogenous Factors: Workers at the Tobacco Factory of Seville During the Industrialization Process, 1887-1945
}

\author{
LINA GÁlveZ-MuÑoz
}

\author{
“TO BE A HUSBAND OF A CIGARRERA WAS A \\ PROFESSION", 2
}

The organization of production by employers was not indifferent to gender. ${ }^{3}$ Labour markets were sexually differentiated, ${ }^{4}$ since women and men were considered to be distinct labour forces distinguished by virtue of the differing roles they were supposed to play. The male role was that of the breadwinner, and the fact that this often reflected the reality of the situation should not obscure the point that it was a social construction. Women, on the other hand, were considered as mostly occupied with unpaid domestic work, regardless of whether they were also engaged in work for the market. Breadwinning patterns have been widely debated, particularly with respect to whether the male breadwinner system appeared as a result of industrialization or existed previously as a consequence of a universal system of patriarchy. In parallel with a more cyclical conception of industrialization, recent studies on breadwinner patterns ${ }^{5}$ do not support theories based on capitalism or patriarchy but rather support a more historical approach based on the

${ }^{1}$ I would like to thank Olwen Hufton, Angélique Janssens, William R. Day Jr, Lavan Mahadeva, Susảna García Cerveró and Alfredo Huertas-Rubio.

2 Interview with J.L.B., retired labour inspector, January 1995.

${ }^{3}$ Recent studies conceming different periods and economic sectors show how employers used different methods depending on the gender of the workers they could hire. E. Jordan's study of the exclusion of women from industries in nineteenth-century Britain is very revealing: "The Exclusion of Women from Industry in Nineteenth-Century Britain", Comparative Studies in Society and History, 31 (1989), pp. 273-296. Actually, employers imposed part-time working only when they could hire women. See S. Walby, Patriarchy at Work (Cambridge, 1986) and V. Beechey and T. Perkins, A Matter of Hours. Women, Part-time work and the Labour Market (Cambridge, 1987).

4 J. Bumette, "Testing for Occupational Crowding in Eighteenth Century British Agriculture", Explorations in Economic History, 33 (1996), pp. 319-345, examining occupational crowding in eighteenth-century British agriculture, demonstrates that men and women were interchangeable in the unskilled workforce. "If the agricultural labour market was not characterized by occupational crowding, this tells us something about where discrimination was located. Gender discrimination originated, not in the competitive market, but in other institutions such as the family, the law, and distributional coalitions" (p. 341). Nevertheless, even if men and women were seen as different labour forces because of differences in productivity rates, it is necessary to study the interaction between the market and the family in order to understand market and family gender differences.

"For a reappraisal, see C. Creighton, "The Rise of the Male Breadwinner Family: A Reappraisal". Comparative Studies in Society and History, 38 (1996), pp. 310-337.

International Review of Social History 42 (1997), Supplement, pp. 87-128 
importance of other exogenous factors ${ }^{6}$ such as the regional economy, the local labour market and the customs and associations acting upon it, employers' choices or the legal and institutional framework. The following paper is a case study related to working-class women, the cigarreras, who were the main wage earners in the family. It relates to an industry (tobacco) which operated under a monopoly system, and to a particular region (southern Spain), which was fairly underdeveloped in terms of industry. This paper examines from a micro-perspective the universality of patriarchal breadwinner patterns, the discontinuity of the industrialization process, and the importance of other exogenous factors in explaining patterns of breadwinning. It asks whether changing exogenous factors during the industrialization process make it possible for a female breadwinner and male househusband model to arise.

The male breadwinner family was itself a social construct requiring historical explanation. Studies of pre-industrial families, micro-analysis on a comparative basis, and the consideration of alternative sources ${ }^{7}$ have emphasized the diversity of routes and outcomes of the male breadwinner family. The choice of a micro-analysis approach to the issue of breadwinning patterns is due to the fact that this type of approach facilitates discussion of a broad range of explanatory factors. ${ }^{8}$ Nevertheless, the introduction of such a wide range of factors is not sufficient in itself to explain the interrelationship between the family and the market. It is necessary to study female and male employment rates from the same perspective. Recent studies have demonstrated in particular the importance of the local labour market in explaining female participation. Other elements such as income effects from the husband's earnings, the family life cycle, and institutional constraints have still remained important variables explaining

- Exogenous factors means factors outside the family economy and outside the family decision-making processes. Although capitalism, as a particular social and economic structure in society, and patriarchy, as a system of values structures and relations, are also family exogenous factors, this paper will name as exogenous factors other factors. These reveal a higher degree of heterogeneity in space and time, such as the regional economy, local labour market, employer's choices, laws, institutions, customs and culture.

7 The studies by N. Folbre, "Patriarchy in Colonial New England", The Review of Radical Political Economics, 12 (1980), pp. 4-75, and C. Sarasúa, "The Rise of the Wage Worker. Peasant Families and the Organization of Work in Modern Spain" (Ph.D., European University Institute, 1995), are especially interesting on pre-industrial family economies. The convenience of using alternative sources is clear in the results obtained by $S$. Horrell and J. Humphries, "Women's Labour Force Participation and the Transition to the MaleBreadwinner Family, 1790-1865", Economic History Review, XLVIII (1995), pp. 89-117, and the contribution by the same authors in this volume.

"Creighton has recently voiced the following criticism: "while the increasing diversity of approaches has highlighted a wider range of factors relevant to the problem, we are in many ways further than ever from achieving their integration into a coherent whole. Each account has focused on a narrow range of determinants and has attributed excessive importance to their consequences" (Creighton, "The Rise of the Male Breadwinner Family", p. 333). 
women's behaviour. Oddly, however, the same set of variables has not been used to advance an explanation of male participation rates in the labour market. Evidently, the idea that male occupations could be influenced by the wife's employment has not been contemplated, nor has the idea of concentration in particular jobs available in the local labour market and not in others. In most cases, the wife's job will not have been the principal source of household income, but it should not be taken for granted that this was always the case. It is necessary to distinguish among working-class women and to de-aggregate the "statistical category" of women and children. Only by studying women and men from the same perspective is it possible to understand the interrelationship between the family and the market in explaining breadwinning patterns. The cigarreras were skilled workers who continued in the workplace until old age and in most cases had the most important job in the family. This fact, in addition to the structure of the local labour market and the set of exogenous factors, conditioned the labour participation rates of the remaining family members, including husbands.

A study of the interrelationship between the family and the labour market which takes into account such a large range of different factors is rendered feasible by the diversity of the sources employed. The documentation consists of national and municipal population censuses, industrial municipal censuses, labour department records, newspapers and photographs, literature, oral history, and above all the comprehensive factory records which contain material relating to virtually every aspect of the tobacco market and industry and the management of the factory. Based on personnel records and other factory records found in the Archivo de la Fábrica de Tabacos de Sevilla (AFTS), it has been possible to create a database for 3,000 workers. This information has been cross-referenced with the 1924 municipal census for the most important working-class neighbourhood of the town, Triana, in order to facilitate a detailed analysis of family structure and economy. Owing to the deficiencies of the census data, this analysis reveals the necessity of supplementing these sources of information on working-class families with other kinds of material, such as factory records. For example, only 25 per cent of the cigarreras identified were registered as cigarreras in the census. In addition, a database of 730 families from the Triana neighbourhood has been created in order to study the differences between cigarreras' and other working-class families. Further research based mainly on other factory records of a different labour profile will reveal more about the most common census categories of working-class families: "at home" for women and "day-labourer" for men. ${ }^{9}$

This analysis was conducted jointly with Eloisa Baena. The tobacco workers database based on factory records and her research on the pottery industry were cross-referenced with municipal censuses of 1900 and 1924. 
This article analyses first of all the cigarreras' life cycle, with reference mainly to their working conditions and household model in the context of the Seville labour market. Second, it deals with the interrelationship between the family and the market during the industrialization process and the consolidation of the male breadwinner system.

\section{THE CIGARRERAS OF SEVILLE: THEIR WORK AND FAMILIES}

The cigarreras' household model and its interaction with the market can be understood only in relationship to their labour career: continuing in the factory after marriage and throughout life. An examination of the literature shows that the traditional, or more common, profile of the working woman employed in industry (which is to say young and single) was not universal. Women often continued to work more or less regularly provided the labour market offered opportunities for them to do so, whilst childbearing did not always lead to a separation from the labour market. ${ }^{10}$ Some women left the market when their children were able to replace them in work and thus supplement the family income, ${ }^{11}$ while others never left, as in the case studied here. Despite this diversity, female industrial time normally appears to have been subordinated to family time, and particularly to the timing of major demographic events. ${ }^{12}$ As a general rule, women have been traditionally identified with unskilled labour and their work has always been considered subordinate to family time throughout life. ${ }^{13}$ The example of the cigarreras ${ }^{14}$ shows, however, that when women were in

${ }^{10}$ See especially Horrell and Humphries, "Women's Labour Force Participation' about women's labour force participation and Jordan, "The Exclusion of Women" about the exclusion of women from industry in nineteenth-century Britain. M. Barrett, "Reply to Brenner and Ramas", New Left Review, 146 (1984), pp. 123-128, and Creighton. "The Rise of the Male Breadwinner Family", criticize the underestimation of alternative arrangements for female biological determinism. J. Norris, “'Well Fitted for Females'. Women in the Macclesfield Silk Industry", in A. Jowitt and A.J. McIvor (eds), Employers and Labour in the English Textile Industries, 1850-1939 (London, 1988), pp. 187-202, demonstrates that the employment of married women in the manufacturing areas in which they were most heavily concentrated actually rose in the second half of the nineteenth century.

"See the contribution by Sara Horrell and Jane Humphries in this volume.

12 "If the term 'industrial time' designates the new time schedules and work disciplines imposed by the industrial system, 'family time' refers to the internal and extemal timing of family behaviour at different stages of individual and family development, particularly to the timing of major demographic events [...]": T. Hareven (ed.), Family and Kin in Urban Communities, 1700-1930 (New York, 1977), p. 189.

${ }^{13}$ For a critical view of the treatment of women's work in economic theory see the compilations made by Alice H. Amsden, The Economics of Women and Work (London, 1980) and recently by Jane Humphries (ed.), Gender and Economics (Basingstoke, 1995).

14 Although analyses concerning cigarreras' breadwinning patterns in other Spanish factories have not yet been done, the labour conditions were similar, as shown in C. Candela Soto, "Trabajo y organización en la industria del tabaco: las cigarreras madrileñas, 1890- 
demand in the labour market, when they were craft workers and breadwinners, and especially when conditions were favourable to the flexible use of time and to childrearing, women could in the long run be as independent of family time as male workers. In the short run, however, it is more difficult to find evidence of men sharing household work in the day-to-day life of the family.

In order to understand the life patterns of the cigarreras during the period studied, it is necessary to analyse their working conditions in the context of the financial and market situation of the company, the legal, institutional and cultural framework of the locality, and their household economy model. It is also necessary to study the opportunities offered by the local labour market to the other members of their families, and more especially to their husbands. This part of the analysis endeavours to avoid the reductionism of explaining the working lives of women solely in terms of gender and likewise the working lives of men solely in terms of labour. Careful consideration is therefore given to the active role played by women's occupations in their husbands' choices of occupation. In such a way, it is possible to address the working conditions and life patterns of the cigarreras in conjunction with the local labour market and the household economy.

\section{The factory and life pattern}

\section{The factory}

From the early seventeenth century, Spanish tobacco production was concentrated in Seville under a centralized manufacturing system. ${ }^{15}$ In 1637 ,

1920", Sociología del trabajo, 20 (1993-1994), pp. 91-115; E. Baena Luque, Las cigarreras sevillanas. Un mito en declive. 1887-1923 (Malaga, 1993); C. Valdés Chápuli, La Fábrica de Tabacos de Alicante (Alicante, 1989); L. Alonso Alvarez, "De la manufactura a la industria: La Real Fábrica de Tabacos de la Conuña (1804-1857)", Historia Económica, 3 (1984), pp. 13-34; and P. Radcliff, "Elite Women Workers and Collective Action: The Cigarette Makers of Gijón, 1890-1930", Journal of Social History, 27 (1993/ 1994), pp. 85-108. The model of the female cigar-maker extends beyond the Spanish border, mainly to France and Italy, where the tobacco industries were state-owned and production was carried out by skilled female cigar-makers. For France, see M. ZylberbergHocquard, "Les ouvrières d'Etat (Tabacs-Alluments) dans les demières années du XIXème siècle", Le mow'ement social, 105 (1978), pp. 87-107, and J.N. Retière, "Une Entreprise d'Etat Séculaire: Les Tabacs l'example de la 'Manu' de Nantes (1857-1914)", Entreprise et Histoire, 6 (1995), pp. 109-127. For Italy, see P. Nava, La fabbrica dell' emancipazione. Operaie della Manifattura Tabacchi di Modena: storie di vita e di lavoro (Rome, 1986).

is On the history of the Spanish tobacco industry, see J. Pérez Vidal, España en la Historia del Tabaco (Madrid, 1959); J. García de Torres, El rabaco: consideraciones sobre el pasado, presente y porvenir de esta renta (Madrid, 1875); E. Delgado, La Renta de tabacos (Madrid, 1892); and J.M. Rodríguez Gordillo, "La Real Fábrica de Tabacos de Sevilla", in idem, Sevilla y el Tabaco (Seville, 1984), pp. 68-75, and idem, "Sobre la industria sevillana del tabaco a fines del siglo XVII", Cuadernos de Historia, VII (1977), 
the state created a fiscal monopoly. By 1887 , which is the start of the period covered by this study, the tobacco industry contributed 12 per cent of state revenues ${ }^{16}$ and the over 30,000 workers in this industry represented 3 per cent of the Spanish industrial population. ${ }^{17}$ At this date, there were ten factories in Spain, most of them created during the nineteenth century as a consequence of expansion and changes in consumption patterns. The Seville factory, the oldest and most important belonging to the state tobacco monopoly, had around 7,000 workers. However, the cost of sustaining the previous rapid growth in production had by this time become very high. The Treasury was unable to invest in modernizing the factories because the state was interested only in fiscal receipts and in avoiding social unrest regarding a necessary labour reconversion. Instead, it decided to lease the management of the tobacco monopoly to a private company, the Compañía Arrendataria de Tabacos (CAT), which could make the capital investment necessary to achieve further large increases in production. This company managed the monopoly from 1887 to 1945 . The legacy of state management was a disequilibrium between market demand and supply of the product, and a fully manual production structure dependent on a skilled female labour force. This case study embraces the period during which management was, in effect, privatized, and in which the company was adapting its production and marketing to mechanized production techniques. As a consequence, the company needed a flexible mode of production and a flexible workforce.

\section{The gendered organization of work}

The gendered division of labour was well defined in the tobacco factory at Seville. At the end of the nineteenth century, male tabaqueros were in charge of the supervision of the factory building, the services inside the plant, the maintenance of the engines and machinery, and the repair and

pp. 533-552. For the importance of the tobacco monopoly to the state, see F. Comín, and P. Martín-Aceña (eds), Empresa Pública e industrialización en España (Madrid, 1990); L. Alonso Alvarez, "La modernización de la industria del tabaco en España, 1800-1935", Working paper, Programa de Historia Económica. Fundación Empresa Pública Madrid, 1993); and idem, "Estrategias empresariales de los monopolios españoles: de la gestión pública a la gestión privada en el estanco del tabaco, 1887-1936", in F. Comín (ed.), La empresa en la historia de España (Madrid, 1996), pp. 383-398. For tobacco consumption. see J. Castañeda, El consumo de tabaco en España y sus factores (Madrid, 1936).

16 The percentage that the tobacco monopoly surrendered to ordinary treasury incomes was 13 per cent in 1850, 12 per cent in 1900, 7 per cent in 1935 and 2 per cent in 1970 (F. Comín, "El sector público", in A. Carreras (ed.), Estadísticas históricas de España, siglos XIX y XX (Madrid, 1989), pp. 399-460, esp. p. 404. Under its 1887 contract, the CAT had to pay an annual fee of 90 million Pts. Several changes in the contract established a proportional fee to be paid to the Treasury. During the CAT period, this varied from 90 to 95 per cent of tobacco industry incomes.

"See Alonso Alvarez, "La modemización de la industria del tabaco". 
maintenance of the factory itself. Processes in the production workshops were carried out exclusively by cigarreras. In the factory, there were different types of workshops related to the different products, or to the different stages in the production chain. At the same time, there was a technical division of labour inside the workshops. This specialization was one of the modernizing goals of the CAT, which was realized with the increased mechanization of work. Apart from these differences, all the cigarreras had specific tobacco manufacturing skills and all of them (except for the porteras and maestras) worked in groups on piece-work rates. ${ }^{18}$ This gave them a great deal of freedom in their working hours, certainly far exceeding that of the tabaqueros who had individualized jobs and were paid fixed salaries. During the period studied, the mechanization of the production process resulted in a dramatic change in the composition of the labour force with respect to gender. In 1896, 5,238 cigarreras and 99 tabaqueros were employed in the factory, but by 1944 the number of cigarreras had dropped to 365 while the number of tabaqueros had more than doubled to 191. That is to say, throughout the period - and even beyond it - the tabaqueros increased in number while the cigarreras declined, mainly because no new cigarreras were taken on (except during two periods). Cigarreras continued to be employed in production workshops and tabaqueros in all areas of work relating to the maintenance of the machines and of the factory itself. The change in the proportion of male to female in the factory was related to a change in capital accumulation and intensification. As shown below, it brought important changes in the cigarreras' family labour strategies and household economy model.

\section{Life cycle}

Under CAT management, the average duration of employment of tabaqueros in the factory was 15 years, while that of the cigarreras was 48 years. ${ }^{19}$ The duration of the working life and the natural life of the cigarre-

18 The organization was the same in all workshops: between six and ten cigarreras worked around a table called a rancho, directed by an ama de rancho who was charged with the distribution of tobacco, tasks and wages, and the maintenance of order and cleanliness on the rancho. A number of ranchos made up a taller, a workshop, directed by the maestra, who was the major authority in the workshop, having sole responsibility for the supervision of production and order. She also had to report the functioning and performance of the workshop to the head of the factory. The oldest maestras became porteras, who sat at the entrance of each workshop to register all comings and goings and to inspect all workers leaving the factory to prevent the theft of tobacco.

${ }^{19}$ H.M. Boot, "How Skilled were Lancashire Cotton Factory Workers in 1833?", Economic History Review, XLVIII (1995), pp. 283-303, in his estimation of Lancashire cotton factory workers' lifetime eaming profiles, subtracted for female workers 7.5 years for childbearing and six months lost through sickness, leaving a working life of 23 years working compared with 35 years for males. For the cigarreras, it is necessary to subtract from 48 years, the 18 per cent average absenteeism during this period; the new average working life in terms of eaming is then 39 years. 
Table la. Average length of the services by marital and family status of cigarreras

\begin{tabular}{lll}
\hline Status & Average years & Sample size \\
\hline Married & 45 & 462 \\
Single & 47 & 164 \\
Widow & 38 & 5 \\
Married-widow(1) & 55 & 299 \\
Head of houschold & 55 & 26 \\
Dependent & 50 & 47 \\
\hline
\end{tabular}

(1) Married-widow must be distinguished from those who were already widows when they were hired.

ras were almost identical (Table 1a). Most of them entered the factory as girls and continued there until retirement or death. The majority of vacancies in the factory were due to deaths or transfer to the Faenas auxiliares workshop, a euphemism for retirement. Under CAT management, women were not taken on before the age of sixteen and recruitment was concentrated in two periods. As a consequence, the average duration of the cigarreras' working lives become shorter. In fact, the recruitment period seems to have been the most important factor determining the average span of a cigarrera's working life (see Table 1b). Even if further estimations need to be done in order to establish which variables are relevant in explaining the length of service of cigarreras in the factory, a set of simple regressions has been run. First, the dependent variable "years worked in the factory" has been regressed out for each of the regressors separately: husband's profession, literacy, and CAT hiring policy (model 1, model 2 and model 3). ${ }^{20}$ Only CAT hiring policy appears to play a role in explaining the variable of interest. Furthermore, R-square values suggest an extremely poor explanatory power of the other two regressors. Second, in another simple exercise, the dependent variable has been regressed with all the regressors at the same time (model 4). As expected, the results confirmed the previous conclusions: the labour policy of the firm seemed to be the sole determinant of the years spent in the factory by the cigarreras. Again, both $\mathrm{R}$-square and $\mathrm{T}$ values point to a high level of significance. The evidence suggests that the factory's criteria for the recruitment of skilled labour were not related to school attendance, and that a permanent tenure was determined more by the specific skills of the cigarreras. There is a positive correlation between the professional category and the years spent in the factory: more responsibility and higher wages mean a longer duration of employment. The average duration was 25 years for barrenderas (sweepers), 47 for cigarreras, 56 for amas de rancho, and 64 for maestras, who finished their days working as porteras sitting in a chair at the door of the workshop.

20 See Table $1 b$ for an explanation on how they were constructed. 


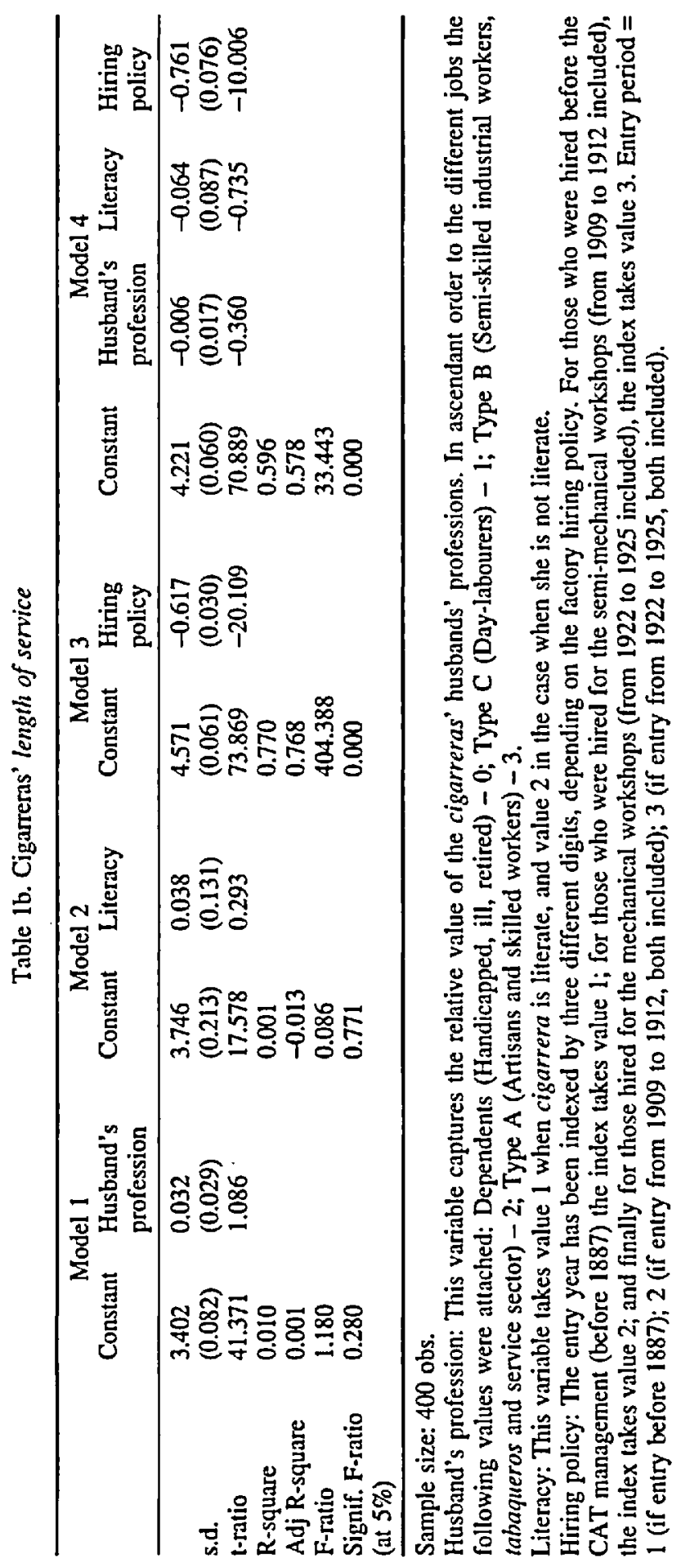


Apart from the monopolistic structure of the firm, there are two main sets of reasons explaining why the CAT continued to practise lifetime employment of these workers even while it was modernizing the company. The first relates to labour considerations and the flexibility needed by the company during the mechanization process; the second is political, relating to historical links between the factory and the town, and the state connection.

In so far as the labour considerations are concerned, it was significant that the cigarreras were skilled workers. When production was based on manual tasks, they controlled production and the apprenticeship system. During the transition from a manual to a mechanized system, the company did not want to introduce any new workers in the manual workshop. New cigarreras were only employed in the mechanized workshops. The factory nevertheless retained the old cigarreras in the manual workshops, first because manual production was still important and second, in order to allow for possible consumer preferences for manually produced cigars and cigarettes, which might necessitate the training of new workers in manual techniques. Also, in the context of their skills and the transitional period, the existence of highly suitable workshops made it possible to transfer workers between different workshops, depending on the production needs. Finally, the factory continued to have a demand for the work of elderly cigarreras in the desvenados (stemmers) workshops, ${ }^{21}$ where tasks were relatively easy and less well paid. One of the main managerial strategies was to transfer elderly cigarreras to more menial tasks, complementing mechanized workshop production. In order to employ the elderly workers, the Faenas auxiliares workshop was created in the Seville tobacco factory in 1905. This workshop was a sort of "nursing home" where old or handicapped cigarreras could be sent to perform auxiliary tasks such as the sewing of sacks. From the 1920s, however, this workshop ceased to exist physically in the factory and the term began to be used as a euphemism for retirement, which was still not regulated.

The second set of reasons concerning the continued employment of cigarreras relate to the difficulties that the factory encountered in its efforts to displace them. The Seville tobacco factory played an important socio-economic and political role in the city. Because the factory was a state-owned enterprise, it also constituted a link between the government

${ }^{21}$ In the tobacco factory at Seville there were four different types of workshops. The base-workshop was the desvenado where the "stemmers" stripped away the midrib of the leaf, leaving the tobacco for the picaduras (cut tobacco) and cigarette workshops. It was an unskilled task and for this reason the cigarreras who worked in this workshop were the old ones who had lost their ability to make cigars or cigarettes. The other workshops were the picaduras, cigarettes and cigars. The cigar workshop was the place where the most skilled cigarreras were employed, because cigar-making was a very complicated and specialized task. 
and the local elite, which continuously practised a procedure based on references trying to send workers to the factory. ${ }^{22}$ For this reason, labour measures in the factory always attracted a great deal of attention from both local government and public opinion. ${ }^{23}$ In the 1887 contract, the state prohibited the company from firing more than 25 per cent of the workforce. This was an attempt to avoid both social unrest and the local economic consequences of firing a large number of workers. In fact, whenever the cigarreras went on strike, the whole town supported them and shopkeepers, for instance, closed their shops during such periods. Whenever the factory was closed because of internal revolts, local government representatives always intervened to seek its reopening. These local and governmental pressures were accompanied by worker and union pressures to preserve the existing labour supply structure.

The loyalty of the cigarreras to the factory was three-fold, consisting of a family economy factor (mostly related to gender), a labour factor and a cultural factor. The first factor related to the importance of the cigarreras to the family economy. As will be illustrated in the next section, the cigarreras were in many cases breadwinners and their wages were always central to the family budget. Apart from the unquestionable importance of maintaining a household, if the fact of being breadwinner cannot be differentiated along gender lines with regard to the individual's life cycle, the use of time and childcare did determine female much more than male labour behaviour. In the long run, cigarreras could be as independent of the family life cycle as male workers, because they were allowed to bring their children with them to the factory and to work flexible hours. Indeed, their flexible schedule was actually facilitated by the collusion of the factory itself in worker non-

${ }^{22}$ See footnote 65 .

${ }^{23}$ The strong influence exercised by local elites and the government in their effort to avoid unpopular measures in the factory suggests that the factory itself was used as a stabilizing factor in the labour market. C. Arenas Posadas, Sevilla y el Estado. Una perspectiva local de la formación del capitalismo en España (Seville, 1993), pp. 298-305, maintains that the factory did not have a positive spillover effect on the Seville economy except in the labour market. He articulated a theory which partly attributes the survival of sonie other local industries to the fact that the factory was able to guarantee a secure wage for more than six thousand working women and their families, thus allowing the local bourgeoisie to fix low wages in their own industries and ensure their continued survival. In support of this theory, he has noted that the first newspapers to alert cigarreras to the potential consequences of the introduction of machinery into the factory, and to the attendant risk of job losses, were those of the bourgeoisie. This author failed in not ascribing importance to the tobacco manufacture in the local economy other than the labour market. During the nineteenth and the twentieth centuries, this huge factory had positive spillover effects on other city industries, even if the tobacco (input) and some complementary inputs together with the machinery came from other places. But even if he exaggerates the importance of the factory to the survival of other local industries because of cigarreras' wages, he does show the importance that everything concemed with the factory had in Seville. Therefore, this factory is an ideal place in which to observe how political clientelism worked. 
attendance. ${ }^{24}$ These circumstances enabled the cigarreras to combine their own household work with factory work. These two factors of part-time employment and childcare helped to make it possible for there to be an increase in labour participation rates among married women in the twentieth century. ${ }^{25}$ With regard to childcare, the factory provided cradles to allow women to care for their babies in the workshops. When mechanized workshops were established and younger cigarreras employed in them, the grandmothers took care of the babies in the manual workshop and the mechanical cigarreras went there to breastfeed their children. Finally, a crèche was created in 1943. In addition, maternity leave and job security had always guaranteed flexibility of attendance at the factory, although remuneration for childbirth was not given before $1931 .^{26}$

The cigarreras brought to the factory skills ${ }^{27}$ specific to the monopolistic enterprise, but their general qualifications were rather poor. There were high rates of illiteracy in the factory up to the 1920s, and it was precisely this high level of specific training and low level of general education that helped to tie the cigarreras to the factory. They also had a work culture which anticipated their continued presence in the workplace after marriage and throughout life. ${ }^{28}$ The cigarreras had an important work culture from childhood, when the factory was presented to them as a

${ }^{24}$ See in this article, the section on mothers and work and L. Gálvez-Muñoz, "Management, Labour and Gender: The Use of Time in the Tobacco Factory of Seville", in $O$. Hufton and C. Sarasúa (eds), Gender and the Use of Time (forthcoming).

${ }_{25}$ C. Goldin, Understanding the Gender Gap (New York, 1990), p. 158, explains that changes in participation in the labour force among white married women in the period from 1890 to 1980 are in a very important way related to the reduction of hours of work, to part-time employment and, more recently, to childcare arrangements: "Indeed, the increased participation of women over the long run resulted more from a change in the nature of jobs, such as the decrease in hours of work [...] than from shifts in social norms and attitudes".

${ }_{26}$ The Decreto del seguro de maternidad was implemented by the Republican Regime, 26 May 1931. Years before this, cigarreras had already won the right to sick pay for maternity leave. The state paid 90 Pts for six weeks. In the tobacco factory, breastfeeding had always been done in the workshops. A rule of one hour of breastfeeding per day began to be applied wherever possible, particularly among employees in the mechanized workshops where it was forbidden to breastfeed babies inside the workshop.

27 Following G. Becker, Human Capital (New York, 1964), the training the cigarreras received was completely specific because it did not endow the worker with any skills that might be utilized in other enterprises, especially in this case because of the monopoly. Among the male tobacco labour force in Spain, only a few workers such as escogedores, who were in charge of the selection of tobacco, had specific skills.

28 Article 6 of the Rules of 1927 provided for all cigar-makers older than 60 to be given the opportunity to retire. Nevertheless, there were still many over-60s who entered the Faenas auxiliares workshop after 1927, illustrating the persistence of a work culture of a lifetime in the factory, as well as family economic needs. The earning differences between wages in the desvenados workshops, where all the older cigarreras were employed and the Faenas auxiliares pay were not very high. In any case, the ratio was always variable because the first was piece-work and the second, the Faenas auxiliares allowance, was a fixed amount. 
"family" (a term that always appears in the oral interviews). They had seen their mothers and their grandmothers combine their work in the factory with their household work. ${ }^{29}$

Finally, an aspect relating to this transitional period has to be addressed. At the end of nineteenth century, the proportion of married women in the Seville tobacco factory was 37.3 per cent (and 17.3 per cent widows), while this rose in the twentieth century to 81 per cent. ${ }^{30}$ The difference in the proportion of married women must be explained in part by reference to the labour policy of the company. During the nineteenth century, families provided workers for the factory continuously, from generation to generation. ${ }^{31}$ Between 1887 and 1910, the CAT stopped taking on cigarreras for the factory in Seville. Daughters could not succeed their mothers, and the proportion of married women remaining in the factory throughout life increased. In 1910, when some daughters were once again admitted to the workshops, their mothers had already passed the critical years of childrearing and some of the new workers were already married. Furthermore, when the next major wave of cigarreras was recruited in the $1920 \mathrm{~s}^{32}$ it was just after the economic crisis at the end of World War I, when a regular wage like that earned by the cigarreras was fundamental to the survival of the family.

This combination of elements ensured that the lives of the cigarreras were not characterized by the premature abandonment of the labour market

29 By contrast, the tabaqueros entered the factory after having worked in other jobs. Thus their work culture was more identified with the culture of the union rather than with the culture of the factory. Arenas Posadas, Sevilla y el Estado (1892-1923), p. 620 and Baena Luque, Las cigarreras sevillanas, pp. 123-124, have criticized the lack of solidarity among cigarreras in Seville with the rest of the working class prior to the 1920 s. These authors have seen this attitude in a negative light, without taking into account that their behaviour diverged from that touted in the patriarchal message of the unions (see S.O. Rose, "Gender Antagonism and Class Conflict: Exclusionary Strategies of Male Trade Unionists in Nineteenth-Century Britain", Social History, 13 (1988), pp. 191-208), which exercised a strong influence on the development of the working class (see J. Scott, Gender and the Politics of History (New York, 1988)). During World War I, at roughly the same time as the success of the major unions in Seville and the increase of tabaqueros in the factory. NICOT, the local section of the national cigarreras' and tabaqueros' union was founded. This was also the time of the entry of new cigarreras into the mechanized workshops, where the noise of the machinery replaced the work in groups chatting around a table. The end of this continuous chat was paralleled by a decrease in skills and the obligatory wearing of a uniform in the mechanized workshops, illustrating how the cigarreras' work culture was weakened by mechanization.

30 AFTS Libro de Personal 1891 (sample size: 5,832) and Personnel dossier 1888-1945 (sample size: 1,655 ). In the second, because it covers a whole period and not a specific year, the widows are considered together with the married women.

${ }^{31}$ Sara Horrell and Jane Humphries demonstrate this generational relief in the participation rates of married women in nineteenth-century Britain. See their contribution in this volume. 32 Between 1922 and 1925, around 400 apprentices were admitted to the workshops following a draw among the cigarreras' daughters and granddaughters who wanted to work in the factory. They were between 16 and 30 years old and literate. 
to assume household duties, but rather by absences resulting from a flexible approach to working hours. This evidence suggests that demand, rather than labour supply, explains trends in recruitment to the factory. From the point of view of the household economy, why did women continue to supply such a high proportion of female labour in the factory even after marriage?

\section{The local labour market and the household economy of the cigarreras}

The literature on labour presents women as more unstable workers than men, engaging in the labour market in order to complement regular family income, and therefore justifiably being paid lower wages than men. ${ }^{33}$ The fact that women were so frequently engaged in casual labour, various occupations and part-time jobs has resulted in an underestimation of female workers in census figures, ${ }^{34}$ which have thus tended to reduce already low female employment rates. Moreover, in twentieth-century Spanish censuses, men engaged in casual work were recorded as jornaleros (day labourers), whereas women casual workers were often designated as being su casa and thus ascribed no market occupation. The data provided by the 1900 national census indicate that the female industrial population in Seville was 3,112, although the records of the tobacco factory suggest that more than 4,000 women were employed in that factory alone in the relevant year. As already stated, only 25 per cent of the cigarreras found in factory records in the 1920 s were designated as cigarreras in the municipal census of 1924 . Even if other sources augmented the proportion, the female participation rates in the Seville labour market were not very substantial. ${ }^{35}$

The effects of industrialization on female participation rates have been widely discussed. Optimistic or pessimistic views, arguments for continuity or discontinuity with pre-industrial behaviour, and the notion of exclusion or segregation by industry have all found a place in the debate.

33 J. Bumette, "An Investigation of the Female-Male Wage Gap During the Industrial Revolution in Britain", Economic History Review, 2 (1997), pp. 257-281, has recently demonstrated that in most cases during the Industrial Revolution women were paid market wages and the size of the earning gap should be explained by measurement errors and productivity differences. However, the present article suggests that differences in productivity rates should be explained separately from biological differences, for differences in consumption of calories, human capital and apprenticeship.

${ }^{34}$ For Britain see E. Higgs, "Women, Occupations and Work in the Nineteenth Century Censuses", History Workshop Journal, 23 (1987), pp. 59-80, and for Spanish censuses, see L. Gálvez-Muñoz, "Une approche aux sources statistiques. Les recencements à Seville du 1900, 1910 et 1920", paper given at the European University Institute, mimeo (1993).

${ }^{35}$ In the industrial municipal census of 1906,25 per cent of the industrial population of Seville were women. In the Padron de Retiro Obrero of 1921, 6,560, that is 37 per cent, of the industrial workers were female. For Arenas Posadas, "Sevilla y el Estado (18921923)", p. 409, they constituted the "true proletariat of Seville". 
Women's employment increased in certain sectors yet decreased in others ${ }^{36}$ in as much as some industries employed women while others did not. Certain occupations became recognized as the preserve of one sex or the other ${ }^{37}$ It is emerging that at least part of the reason lay in the different industrial bases of the various regions or towns. Local traditions concerning both the role of married women in the household economy and the demand for female labour in the context of the local labour market, rather than general theories or new ideas, are now considered fundamental to the explanation of female employment rates. ${ }^{38}$

\section{Labour market in Seville}

The main characteristic of the labour market in Seville was its exaggerated size and its dependence on a regional economy based on agricultural exports, always exposed to strong cyclical variations. The city's population grew as a result of immigration, mainly from the Andalusian countryside, ${ }^{39}$ an over-populated latifindio ${ }^{40}$ area where the female monetary con-

36 Horrell and Humphries, "Women's Labour Force Participation", call attention to the timing in the long run. It seems that the industrialization in Britain first increased female opportunities, only to reduce them later.

${ }^{37}$ In opposition to the view that unions played the main role in the exclusion of women from the labour market, Jordan, "The Exclusion of Women", invokes the gender ideology of the period, based on the gendered division of labour established in the new industries. Employers undoubtedly encountered considerable opposition from male trade unionists when they tried to extend their female workforces, but it was the gender ideology of the period which created an androcentric blindness that prevented them from considering the possibility that some of the tasks within their industries could be performed just as well and far more cheaply by women. J. Bumette, "Testing for Occupational Crowding in Eighteenth Century British Agriculture", Explorations in Economic History, 33 (1996), pp. 319345 and idem, "An Investigation of the Female-Male Wage Gap", refers to differences in productivity among male and female workers.

${ }^{38}$ Rose, "Proto-Industry, Women's Work and the Household Economy", as well as L. Tilly and J. Scott, Women, Work and Family (New York, 1978), underline the importance of local traditions and labour market opportunities for family employment rather than new ideologies. The participation of working-class women in the nineteenth century is less the product of new ideas than of the effects of old ideas and pre-industrial values operating in new or changing contexts. Local traditions regarding family employment, rather than new ideologies, may have influenced the reorganization of some industries during the transition to industrial capitalism, resulting in the generation of particular types of employment opportunities for women. See Horrell and Humphries, "Women's Labour Force Participation" and their contribution to this volume; Jordan, "The Exclusion of Women"; and Sarasúa, "The Rise of the Wage Worker", for the Spanish case, have demonstrated the key role of the local labour market in explaining female participation rates.

${ }^{39}$ In the first quarter of the twentieth century the population of Seville increased by 100,000 people - from 140,000 to 250,000 . In 1900 , more than 40 per cent of immigrants came from the surrounding countryside. The proportion including the rest of Andalusia was 85 per cent, and 95 per cent for 1924. See Arenas Posadas, Industria y clases trabajadoras, p. 185.

${ }^{20}$ For the social and economic conditions of latifundio in Andalusia, see A.M. Bemal, Economía e Historia de los latifundios (Madrid, 1988). 
tribution to the household economy is thought to have been only marginal and temporary. Census figures show very low rates of female participation in the labour market during this period, especially in the industrial sector (Table 2). Female employment in the industrial sector almost always accounted for less than 30 per cent of the total female workforce. ${ }^{41}$ The female industrial population of Seville seems to have been concentrated in a few large industries, such as tobacco, armaments, textiles, pottery, and some temporary work relating to the agricultural export industry. ${ }^{42}$ As in the Andalusian countryside, male workers were cheap. As a matter of fact, this labour market was characterized by a low female participation and by a significant number of day labourers. ${ }^{43}$ The industrial sector in Seville was still relatively antiquated in the late nineteenth and twentieth centuries. It was bipartite, with a traditional sector employing artisans and a modern sector employing a large number of unskilled workers. Local employers responded to market fluctuations by varying the size of the workforce rather than by investing in technology. Employment and unemployment were more or less in a constant state of flux, characterized by periods of inactivity, ${ }^{44}$ so that family incomes were determined more by the number of days worked than by nominal wages. In addition, Arenas (1995) has shown that workers with higher nominal wages worked more days a year than those with lower nominal wages.

On average, the factory functioned for about 280 days a year, representing one of the more stable workplaces in the city. As can be seen in Table 3 and Figures 1-3, the advantages of the cigarreras' wages were

${ }^{41}$ The single exception, according to census figures, occurred in 1920. And the reason seems to be more related with quantification problems than with real changes in the local economy.

${ }^{42}$ See Arenas Posadas, Industria y clases trabajadoras, and E. Baena Luque, "Las trabajadoras sevillanas 1900-1936", in Arenas, Industria y clases trabajadoras, pp. 225-245.

${ }^{13}$ The tobacco factory itself could be taken as an example of the way in which this labour market worked. The factory had established a system of substitutions whereby every moming a limited pool of male workers were admitted into the factory or not according to the number of absences. As a result, tabaqueros endured the pressure of the labour market every morning at the entrance to the factory. If they were late, other workers might take their jobs and their wages for the day. This policy was also common in other industrial contexts: "In a number of cotton weaving sheds in Lancashire, temporary weavers would come to the mills in the moming and would be given the looms of any permanent weaver who was late, even though the weavers were employed under piece rates. In one mill, if a permanent weaver was five minutes late, she lost her looms for the day": G. Clark, "Factory Discipline", Journal of Economic History, 54 (1994), pp. 128-257, esp. p. 132.

4 Arenas Posadas, "Sevilla y el Estado (1892-1923)", studying a sample of the municipal censuses of 1900 and 1924 and the padrón del retiro obrero of 1921, calculates unemployment as between 20 and 40 per cent. The variation was related to the demand for agroexport customs. For him, these figures are horrific because the only way to survive was public or private charity. Although these figures are certainly horrific, kinship was still a fundamental institution. In fact, it was the family who maintained this inflated labour market. 
Table 2. Occupation ratios in Seville by sex, female marital status and sectors

\begin{tabular}{|c|c|c|c|c|c|c|}
\hline \multicolumn{7}{|c|}{ Occupation rates by sex } \\
\hline Year & Total & Female & & & $\%$ female & $\%$ male \\
\hline $\begin{array}{l}1900 \\
1910 \\
1920 \\
1930 \\
1940\end{array}$ & $\begin{array}{r}56,902 \\
59,735 \\
73,384 \\
84,110 \\
113,706\end{array}$ & $\begin{array}{r}11,012 \\
9,125 \\
8,651 \\
12,806 \\
23,058\end{array}$ & & & $\begin{array}{l}19.40 \\
15.30 \\
11.70 \\
15.30 \\
20.30\end{array}$ & $\begin{array}{l}80.60 \\
84.70 \\
88.30 \\
84.70 \\
79.70\end{array}$ \\
\hline \multicolumn{7}{|c|}{ Marital status (female) } \\
\hline & \multicolumn{2}{|c|}{ Single } & \multicolumn{2}{|c|}{ Married } & \multicolumn{2}{|c|}{ Widow } \\
\hline & Total & $\%$ & Total & $\%$ & Total & $\%$ \\
\hline $\begin{array}{l}1900 \\
1910 \\
1920 \\
1930 \\
1940\end{array}$ & $\begin{array}{r}7,654 \\
6,423 \\
6,503 \\
10,208 \\
18,311\end{array}$ & $\begin{array}{l}69.50 \\
70.40 \\
75.20 \\
79.70 \\
79.40\end{array}$ & $\begin{array}{r}1,425 \\
963 \\
827 \\
858 \\
1,250\end{array}$ & $\begin{array}{r}12.90 \\
10.60 \\
9.60 \\
6.70 \\
5.40\end{array}$ & $\begin{array}{l}1,933 \\
1,739 \\
1,302 \\
1,740 \\
3,490\end{array}$ & $\begin{array}{l}17.60 \\
19.00 \\
15.20 \\
13.60 \\
15.20\end{array}$ \\
\hline \multicolumn{7}{|c|}{ Sectors (female) } \\
\hline & \multicolumn{2}{|c|}{ Agriculture } & \multicolumn{2}{|c|}{ Industry } & \multicolumn{2}{|c|}{ Service } \\
\hline & Total & $\%$ & Total & $\%$ & Total & $\%$ \\
\hline $\begin{array}{l}1900 \\
1910 \\
1920 \\
1930 \\
1940\end{array}$ & $\begin{array}{r}433 \\
237 \\
12 \\
25 \\
252\end{array}$ & $\begin{array}{l}3.90 \\
2.50 \\
0.10 \\
0.20 \\
1.20\end{array}$ & $\begin{array}{l}3,112 \\
2,257 \\
4,481 \\
3,445 \\
5,129\end{array}$ & $\begin{array}{l}28.20 \\
24.80 \\
51.80 \\
26.90 \\
22.30\end{array}$ & $\begin{array}{r}7,467 \\
6.631 \\
4,148 \\
9,339 \\
17,627\end{array}$ & $\begin{array}{l}67.90 \\
72.70 \\
48.10 \\
72.90 \\
76.50\end{array}$ \\
\hline
\end{tabular}

more apparent in their annual incomes than in daily wages. In other words, it is necessary to stress the stability of their employment in an unstable labour market. Apart from their annual income, the cigarreras were guaranteed future security, not only for themselves (faenas auxililares workshop and retirement) but also for their families, in that they were able to arrange work at the factory for their descendants. In addition, they were given free health care, which was also extended in practice to their families. Factory records, literature and oral history suggest that the cigarreras often provided the principal source of income for large families. On the other hand, figures based on municipal censuses (Table 4) show that cigarreras' families had fewer dependants than other working-class families. This is due to the fact that, thanks to factory records, census figures have been corrected for the cigarreras' families. Moreover, the underestimation of female employment in families other than those of the cigarreras is still expressed in these figures, and so caution is required in making comparisons. It must be remembered that men who did not work on a regular basis are recorded as day labourers and women in the same situation as having no occupation. For this reason, the majority of women 
Table 3. Real annual wages (in Pesetas)

\begin{tabular}{lllllll}
\hline Year & Cigarreras & Type-A & \multicolumn{2}{c}{ Type-B worker } & \multicolumn{2}{c}{ Type-C worker } \\
& & worker & Scenario 1 & Scenario 2 & Scenario 1 & Scenario 2 \\
\hline 1909 & 797.88 & $1,374.00$ & 761.80 & 609.44 & 345.80 & 247.00 \\
1910 & 907.28 & $1,575.00$ & 894.40 & 715.52 & 393.12 & 280.80 \\
1911 & 883.70 & $1,626.00$ & 889.20 & 711.36 & 393.12 & 280.80 \\
1912 & 823.77 & $1,617.00$ & 886.60 & 709.28 & 382.20 & 273.00 \\
1913 & 726.12 & $1,479.00$ & 871.00 & 696.80 & 349.44 & 249.60 \\
1914 & 762.15 & $1,536.00$ & 865.80 & 692.64 & 364.00 & 260.00 \\
1915 & 661.64 & $1,362.00$ & 816.40 & 653.12 & 309.40 & 221.00 \\
1916 & 670.86 & $1,458.00$ & 787.80 & 630.24 & 318.50 & 227.50 \\
1917 & 690.55 & $1,320.00$ & 735.80 & 588.64 & 294.84 & 210.60 \\
1918 & 821.13 & $1,341.00$ & 951.60 & 761.28 & 300.30 & 214.50 \\
1919 & 844.29 & $1,260.00$ & 808.60 & 646.88 & 380.38 & 271.70 \\
1920 & 899.45 & $1,389.00$ & 884.00 & 707.20 & 420.42 & 300.30 \\
1921 & 918.30 & - & 824.20 & 659.36 & 393.12 & 280.80 \\
1922 & 835.86 & - & 889.20 & 711.36 & 433.16 & 309.40 \\
\hline
\end{tabular}

Source:

Cigarreras: Average daily wages of Cigarrillos Superiores workshop multiplied by number of days worked in a year.

Type-A worker: Arenas' (1995) estimates of craftsmen, mechanics and skilled industrial workers' daily wages multiplied by full employment (290 days per annum).

Type-B worker: Semi-skilled workers:

Scenario 1 (optimistic = Arenas' estimates multiplied per an average of 4.5 days per week per annum);

Scenario 2 (pessimistic $=$ Arenas' estimates multiplied per an average of 3.5 days per week per annum).

Type-C worker: Day labourers:

Scenario 1 (optimistic = Arenas' estimates multiplied per an average of 3.5 days per week per annum);

Scenario 2 (pessimistic $=$ Arenas' estimates multiplied per an average of 2.5 days per week per annum).

The number of days worked per annum are constant for the whole period studied, except for the cigarreras' case.

Both optimistic and pessimistic scenarios are based on different information related to different years, occupational categories and companies collected by Arenas (1995). Therefore, the trends in annual wages of all type-A, $B$ and $C$ groups are the same as the daily ones.

Table 4. Number of income-less family members, 1924

\begin{tabular}{lll}
\hline & Type & $\begin{array}{l}\text { \% of } \\
\text { income-less }\end{array}$ \\
\hline Families with at least one cigarrera & 1 & 23.4 \\
Householder: female & 2 & 74.0 \\
Householder: day labourer & 3 & 54.9 \\
Householder: semi-skilled and skilled industrial & 4 & 54.7 \\
\hline
\end{tabular}


in working-class families appear as dependants. Moreover, the estimates are based on individual households. The evidence of many working-class households without income substantiates the existence of families extending beyond a single household: families were not always united under a single roof.

\section{Cigarreras' husbands}

The fact that neither marital status ${ }^{45}$ nor position in the household seems to have affected the length of cigarreras' working lives (see Tables 1a and $1 \mathrm{~b})^{46}$ corroborates the notion that their positions were as independent as those of men with respect to the family life cycle in the long run, and suggests that their jobs were often the main source of family income, whether they were married or single. This model concurs with the male model in which the job is considered to have been an important variable explaining the course of male workers' lives. In explaining breadwinner patterns, married cigarreras seem therefore to be more interesting subjects of study than single ones. From a sample of the professions of 400 husbands of cigarreras (see Figure 4), 42 per cent (type C) were jornaleros (day labourers); 25 per cent (type B) were either semi-skilled workers (11.5 per cent), tabaqueros ( 5.5 per cent) or employed in the service sector ( 8 per cent); 28 per cent (type A) were skilled workers; and 5 per cent were otherwise employed, handicapped or dependent for some other reason. Based on the information provided by the municipal census and wages data in Table 3, the earnings of the married cigarreras were probably the principal source of income for their households. The proportion of married cigarreras contributing the main source of income to the family economy varies from 72 per cent of total married cigarreras according to a pessimistic estimate (scenario 2) to 47 per cent in a optimistic estimate (scenario 1). ${ }^{47}$ Table 4 shows that the proportion of cigarreras' wages to family income were similar to that of the householder's income in the other working-class families, except in those families where the householder was a woman. These figures show the scarcity of employment for both male and female workers. The cigarrera's job was often the main

4s However, it may be more interesting to study fertility rates than marital status to explain the length of the cigarreras' working lives. Neither the municipal census of 1924, referring to a specific year, nor the personnel dossier are reliable sources of this information. The only source which gives information about the number of children of cigarreras is oral history, but these data are not susceptible to computation because they are approximate. It seems that the fertility was high according to the rates at the time, and it was encourged by the facilities of the factory.

${ }^{4}$ For an explanation of the construction of Table 1b, see the section on the factory and life pattern, pp. 91-100. Only cases where the husband's profession is known have been used for this regression.

${ }^{47}$ Pessimistic and optimistic estimates are considered in relation to the number of days worked per week. For the construction of both scenarios, see Table 3. 

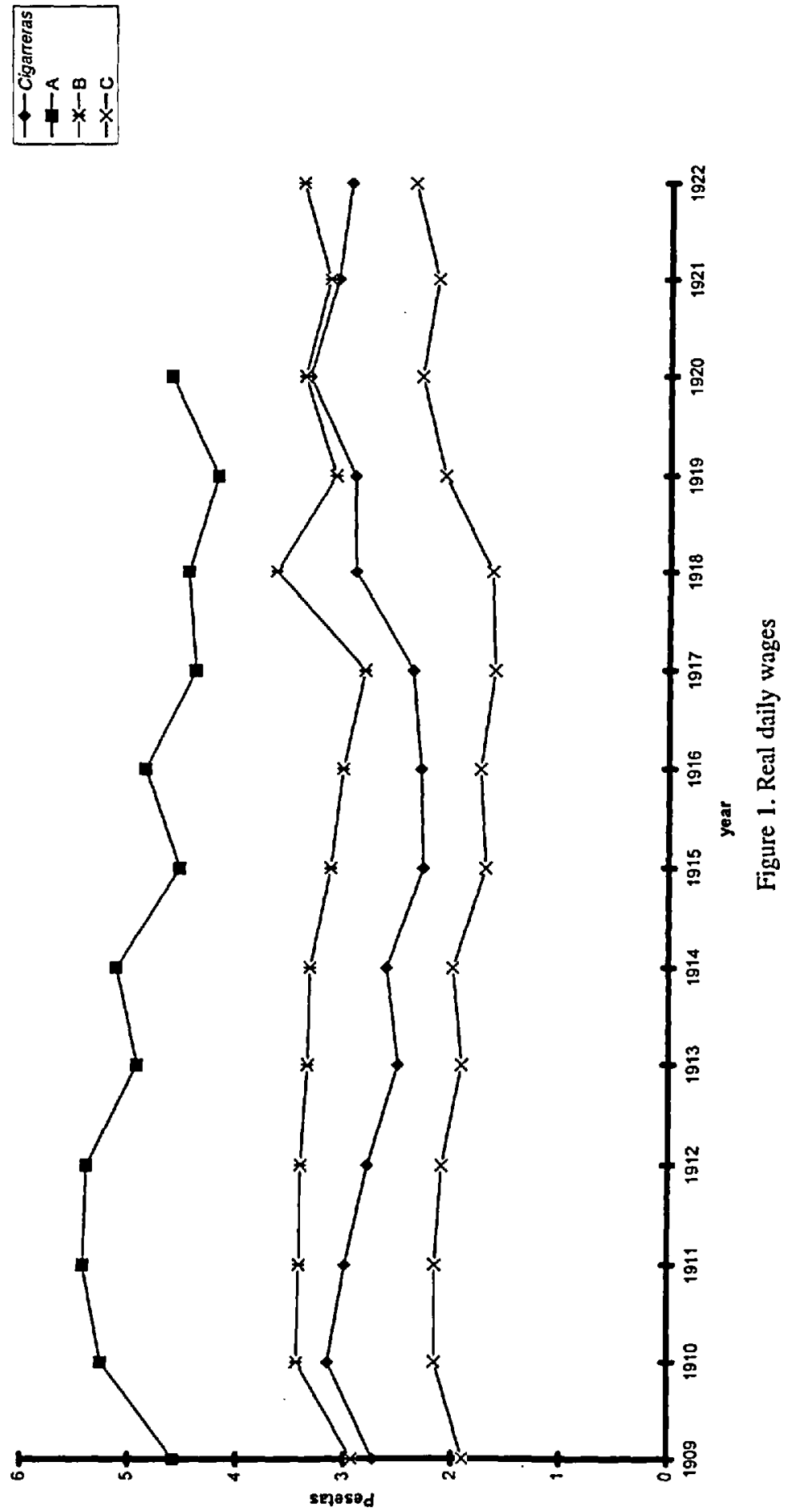

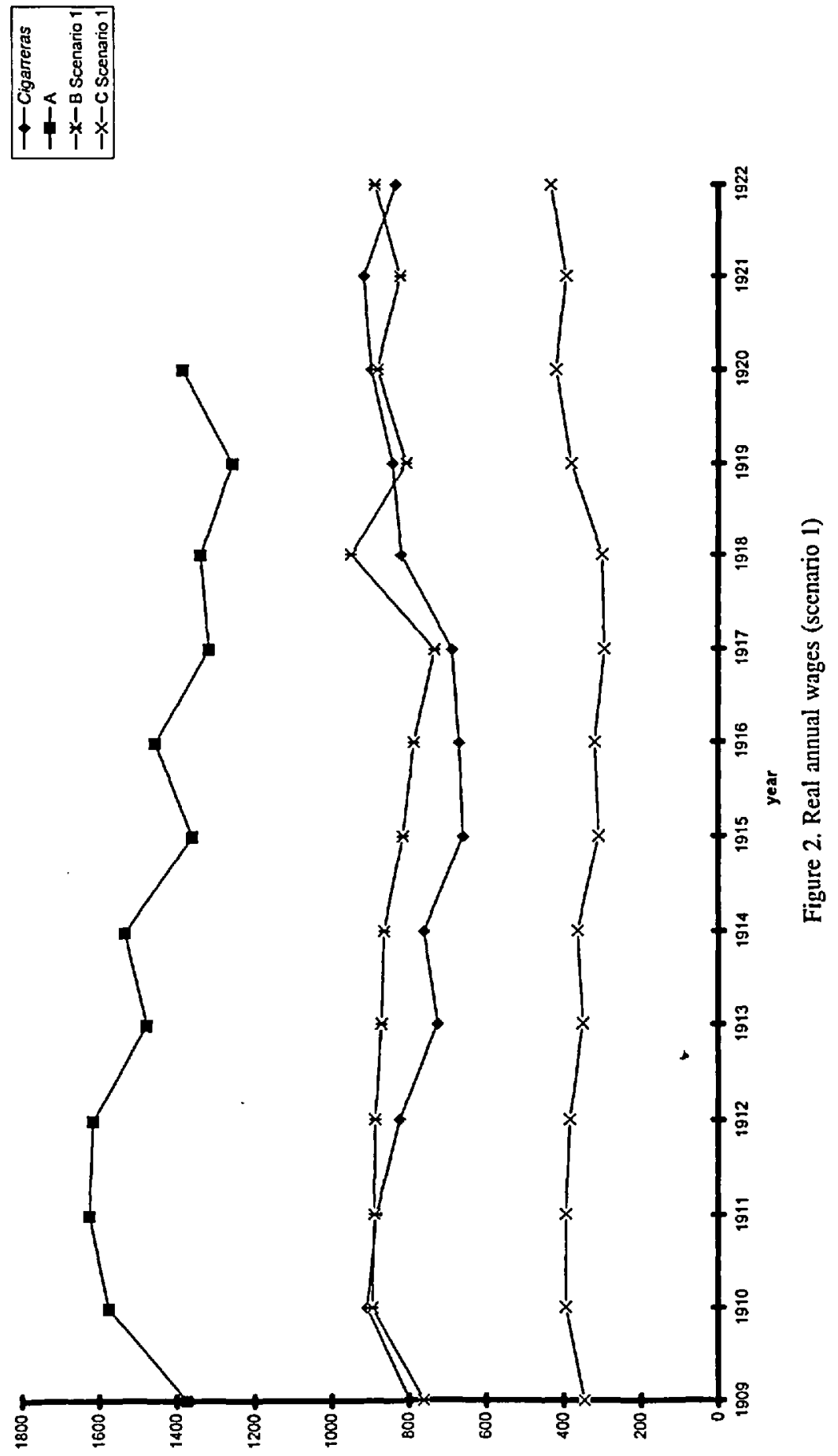

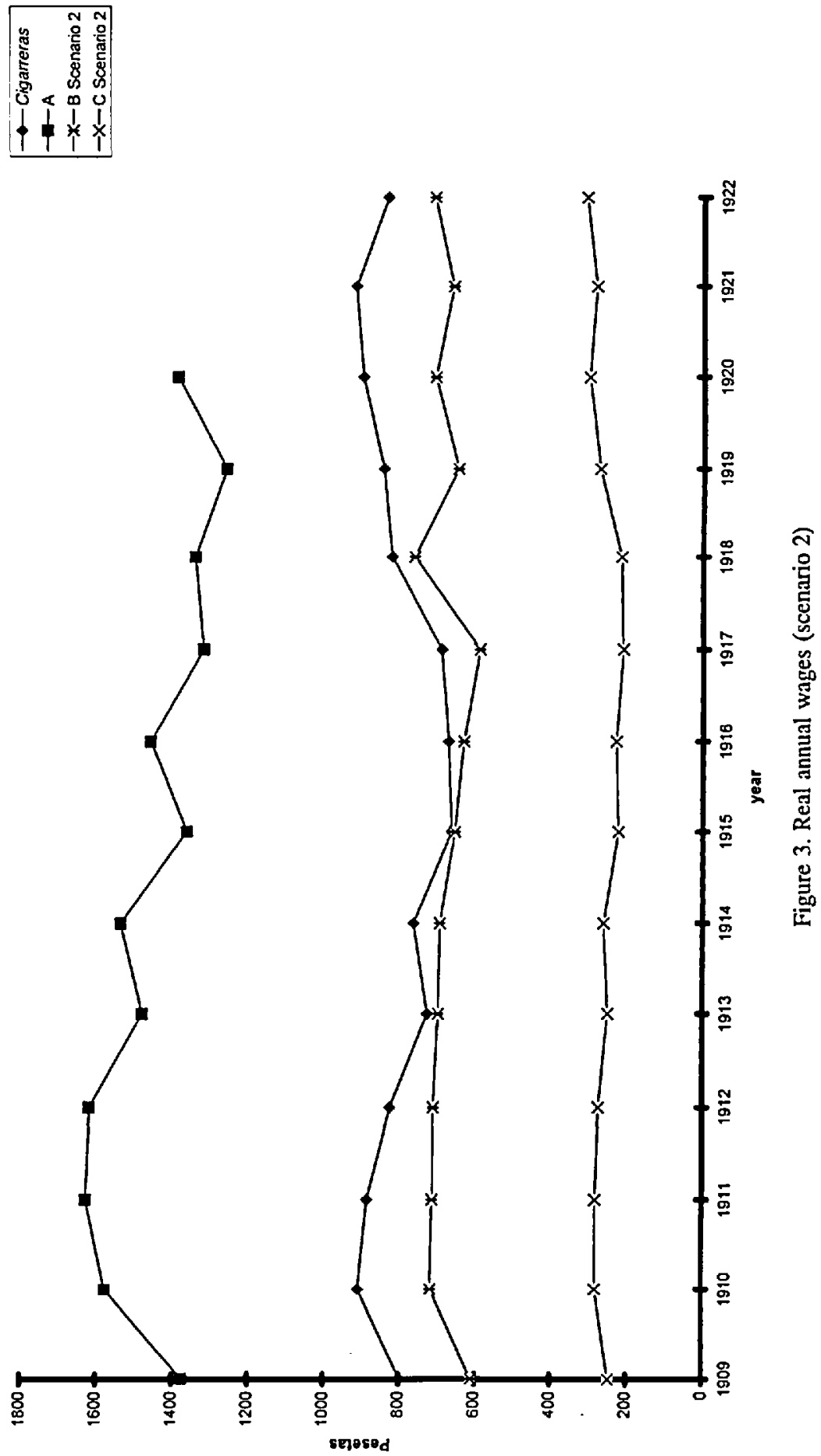


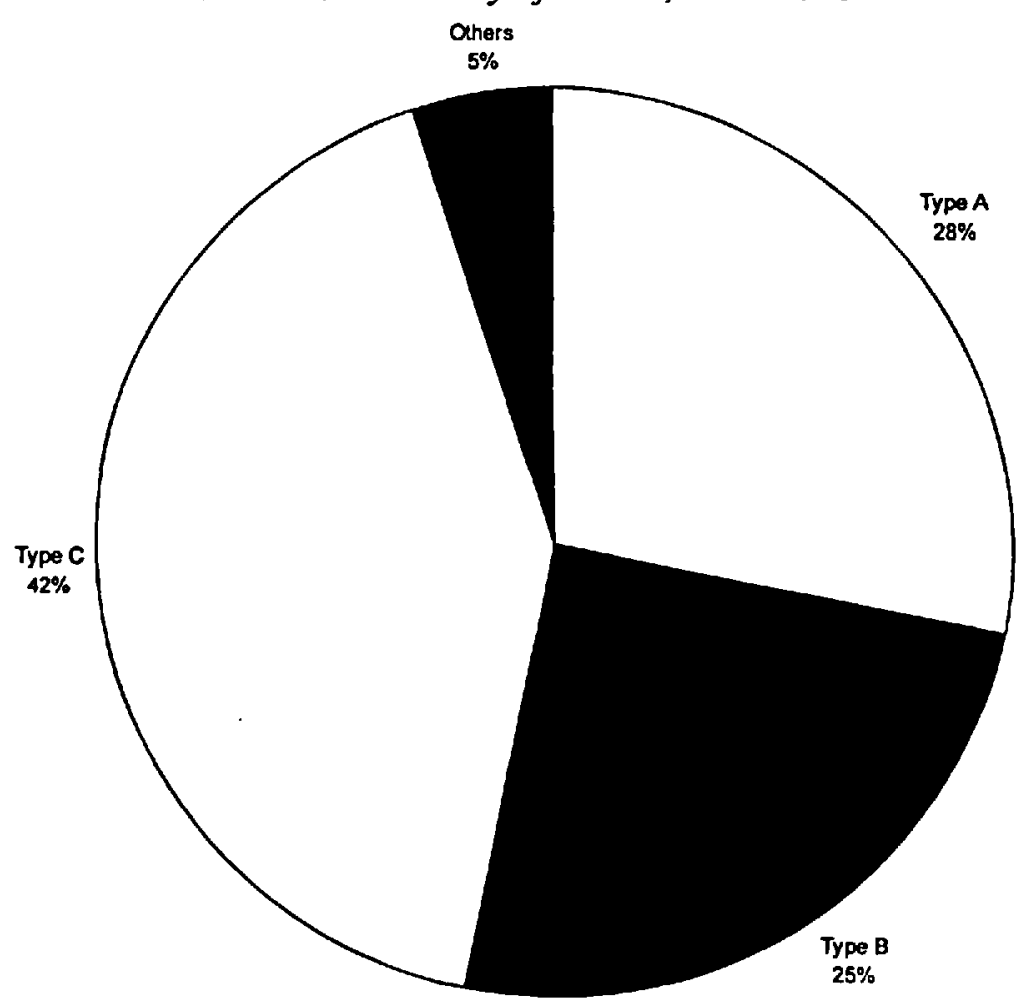

Figure 4. Cigarreras' husbands by type of job

source of employment in the family, not only in terms of actual income, but even more importantly in terms of security. Compared to other local industries in the private sector, the tobacco factory, operating under a monopoly system, constituted the most dependable source of employment in town.

The lack of professional stability of the majority of the cigarreras' husbands helps to explain why cigarreras were attractive prospective marriage partners. The factory exit was always crowded with men waiting to see the women emerge, as in the representations by Merimée and Bizet. Whatever the importance of the Carmen myth to the cigarreras and the collective identity of Seville, it seems that other kinds of interests were also at work in this custom. This can be illustrated not only quantitatively but also qualitatively on the basis of such diverse sources as factory records, literature and oral history. In the period up to 1920, the boss of the factory operated a policy of firing any apprentice who got married. This was illegal under the rules of the company and those fired during these years were readmitted during the 1920s. Personnel records on one cigar-maker dismissed after marriage and later readmitted explain that she 
was never formally married but simply left her mother's house to live in that of her fiance; for the boss of the factory, however, the arrangement was equivalent to marriage. When her fiancé discovered that she had been dismissed by the factory, he left her because he wanted to marry a cigarrera. ${ }^{48}$ Literature, ${ }^{49}$ and more especially oral histories, are even more explicit than the factory records. In their interviews, cigarreras emphasized that not all of their husbands were lazy drunkards but that some certainly were; they speak of bad lick. Perhaps the most revealing statement is that of a labour inspector charged with the task of determining which cigarreras were entitled to receive a family subsidy in the 1940s: "Ser marido de una cigarrera era una profesión" (to be a husband of a cigarrera was a profession), ${ }^{50}$ he declared. If so, then it is possible to say that the wife's job - if the main one in the family - could determine her husband's occupation. Nevertheless, as in explaining female participation in the workforce, the employment behaviour of a cigarrera's husband should not only be related to his wife's employment, but also to the opportunities offered by the local labour market. Arenas (1993) shows that, out of a sample of 4,864 industrial workers in $1921,41.12$ per cent were skilled and 58.88 per cent unskilled. ${ }^{51}$ The same author estimates the rate of unemployment during the first quarter of the twentieth century at between 20 per cent and 40 per cent. ${ }^{52}$ When the cigarreras' daughters ceased to be taken on for work in the factory, they began to press for their sons and also their husbands to be employed there.

The example of the cigarreras shows that a female breadwinner model could exist, and not only in female householder families. But the sexual division of work was not immutable; is the figure of the breadwinner free of household tasks therefore independent of gender?

\section{Cigarreras' households}

The reverse image of the breadwinning wife - the house-husband - did not exist. Instead of cigarreras' unemployed husbands performing household work, there is evidence of cigarreras coming to the factory later in the moming and being absent in order to perform household tasks (see

\footnotetext{
48 AFT Personnel dossiers, 1921. Angeles Castaño Reina.

19 In Palacio Valdés, La hermana San Sulpicio (Madrid, 1887) the confidant of the main character is a cigarrera and her husband is shown in the story as an alcoholic and an idler. so Interview with J.L.B., January 1995.

${ }^{31}$ For Arenas Posadas, "Sevilla y el Estado (1892-1923)", pp. 431-432, the estimates have only a superficial statistical value. He defines this proportion as the arithmetical value of a dual reality in the labour market showing a duality in industry, employing workers with different characteristics.

32 In the municipal poverty census of 1904, families with less than 3 Pts a day were considered poor. There were 16,158 families and 64,632 persons in this category, 60 per cent of the population. Measurement changes reduced this percentage, but it still remained very significant: ibid., p. 418.
} 
section on mothers and workers, pp. 118-126 below). The interview with an elderly shopkeeper in the Triana neighbourhood ${ }^{53}$ corroborates the idea that these women were in charge of everything relating to the household. He remembers seeing them always going about with their children and selling them food already half-prepared for cooking. Although the cigarreras did not share their household tasks with their husbands, conditions in the factory, assistance from female family members and facilities in the neighbourhood seem to have helped them to cope with their double working day. The factory permitted them to bring their babies into the workshops and, in addition, they belonged to extended families who assisted with childcare and other household tasks. Finally, the neighbourhood also helped to mitigate the strain of a lengthy working day in both factory and home. The type of housing in which cigarreras lived, corrales and casas de vecinos, was such that many daily tasks could be collectivized. This included that of caring for children, who were always together in the yard under the supervision of a neighbour. In addition, the religious communities' census of 1900 shows that the Hijas de la Caridad de San Vicente de Paill declared that their occupation was to take care of cigarreras' children while these women were working. ${ }^{54}$

Nevertheless, during the twentieth century the cigarreras' family model became a minority one and began to change. With the CAT's new labour policy of not hiring new apprentices (except in the periods from 1909 to 1912 and 1922 to 1925), many potential cigarreras were excluded from the factory. A reduction both in the number of families dependent on the tobacco industry and in the number of cigarreras per family resulted in a reduction in the financial contribution of cigarreras to the family economy. This loss of family income was in part mitigated by the gender change in the labour strategies that came about as a consequence of the new factory policy and changes in the production process. When it became impossible for the cigarreras to introduce their daughters to the workshops, they began to promote their husbands and sons as prospective factory employees, as can be seen from the many applications for jobs made to the factory. Arenas (1995) sees the diversification of family incomes as common throughout the working classes of Seville during this period, and believes that this has to be related to the process of degradation ${ }^{55}$ of

\footnotetext{
s3 Interview with F.V.G., July 1996.

\$4 Archivo Municipal de Sevilla, Sección estadística.

ss The idea of de-skilling with industrialization has been substituted by that of heterogeneity with regard to changes in the workforce. First, with a redefinition of the concept of skill in the pre-industrial period, M. Berg. The Age of Manufactures. Industry, Innovation and Work in Britain, 1700-1820 (London, 1985) has demonstrated that, with the division of work, skill was sometimes identified with ability or speed. In the majority of cases, the de-skilling process was actually a re-skilling process and in only a few cases was the de-skilling process accompanied by a loss in wages. See W. Lazonick, “Industrial Relations and Technical Change: The Case of the Self-Acting Mule", Cambridge Journal of Economics, III (1979), pp. 231-262, and P.L. Robertson and L.J. Alston, "Technological Choice
} 
pre-industrial skilled workers. ${ }^{56}$ The cigarreras certainly suffered a process of de-skilling, but this did not result in a diversification of family incomes but rather in a shift to the male breadwinner system. ${ }^{57}$ Under CAT management, the workforce of more than 6,000 women was reduced to 300 . This decrease and changes in the ratio between the sexes in the factory workforce should be related to a new phase of capital accumulation, demanding fewer workers directly engaged in production workshops and more engaged in the maintenance of the plant.

Once their daughters could not enter the factory, the cigarreras' families had to face not only the problem of redundant workers but also the necessity of changing the family economic system. As already mentioned in this article, this brought about a gender change in the family labour perspective towards the factory. Further research is required to analyse whether diversification also affected the cigarreras' daughters who were unable to enter the factory. ${ }^{58}$ Although definitive results are not yet available, it seems that these daughters continued waiting to enter the factory and did not seek permanent employment in other industries, so encouraging the slow imposition of the male breadwinner system. This fact must be linked not only to the cigarreras' work culture and the CAT hiring policy, but also to the scarcity of opportunities for women in the Seville labour market. The CAT's new labour policy brought about a decline in the importance of the cigarreras and the female industrial worker over the period studied, and destroyed the traditional family economy model of cigarreras, which may have been one of the very few examples of female breadwinner family models. Even if the fact of being the breadwinner did not imply a reduction in responsibility for household tasks, it did give the women concerned great control of family incomes. Descriptions of the

and the Organization of Work in Capitalist Firms", Economic History Review, XLV (1992), pp. 330-349. That was not the trend in the female skilled labour force, which suffered a pure process of degradation.

${ }_{56}$ Arenas Posadas, Industria y clases trabajadoras, p. 219, maintains that the importance of complementary wages to the overall family income increased during the first quarter of the twentieth century. During this period the contribution of the main wage fell from 78 to 73 per cent of total family income, which seems to confirm the degradation of work. Nevertheless, Arenas considered the diversification of family income and the degradation of skilled workers a negative phenomenon. But in many cases this degradation made it possible for women to have a job and to make a contribution to the family economy, and subsequently changed power relations within the family unit.

37 The idea of re-skilling with industrialization is represented by the adoption of new labour roles, mostly related to supervision in the workshops by the old skilled workers. But the consequences of industrialization in a female labour force appear to have been a purely de-skilling process. Because of patriarchy, women were not considered capable of supervising other workers.

st It is necessary to analyse the cigarreras' family economy in the post-Spanish Civil War period. 
way they dressed, ${ }^{59}$ the factory records punishing market exchanges in the workshops and records demonstrating the opportunities open to them to leave their husbands or to arrange the adoption of their children after they died all show that in most cases they controlled their wages. The industrialization process made this model a thing of the past. It continued to be important in the collective memory of the town but disappeared as a representative reality. How this happened is examined in the next part of this article.

\section{THE INTERACTION BETWEEN THE INDUSTRIALIZATION PROCESS AND FAMILY STRATEGIES}

The industrialization of the tobacco factory in Seville was gradual but effective. ${ }^{60}$ The lease contract established that the CAT had to pay an annual fee of 90 million Pts to the Treasury. ${ }^{61}$ As a consequence of this high annual fee and the market disequilibrium inherited from the state, the company had a negative financial balance during the first three years and this imposed a low investment policy. To make a profit, the CAT needed to increase production by replacing labour with technology. However, a total mechanization of the factories would have required a large capital expenditure and would probably have provoked a popular uprising. Obviously, the state had an interest in preventing such occurrences and did not permit the company to make any radical change in the production process. In fact, the state's contract expressly stipulated that the CAT could not fire more than 25 per cent of the factory's personnel. The size of the industry also made it impossible to invest in technology on a massive scale. During the CAT's first few years of running the industry, there was no major investment in technology. The only investments made focused on two newly established factories, and on the picaduras workshops in the older factories. Workshops producing cigars and cigarettes, where the majority of cigarreras were concentrated, did not experience this investment boost. ${ }^{62}$ This was partly because the Spanish consumer did not easily

\footnotetext{
s9 Photographs and literary descriptions reveal a beautiful way of dressing. Cigarreras were highly concemed about the way they dressed.

$\infty$ Jordan, "The Exclusion of Women", p. 276, says that in nineteenth-century Britain women continued to be employed in industries where the transition to industrialism was gradual, but were excluded from new fields and from industries that underwent radical reorganization.

${ }^{61}$ Contract of Lease of the Tobacco Monopoly for the Production and Sale of Tobacco in the Peninsula, Balearic Islands, Ceuta and the rest site in Northem Africa, 16 June 1887. AHFT, Expedientes generales, Leg. 628.

${ }_{62}$ The CAT already knew that it had to be very prudent in introducing machines to the workforce. For example, the Luddite-inspired revolt of 1885 in the factory at Seville was still a very recent experience. The reason for this insurrection was the rumour of the arrival of cigarette machines. The actual arrival took place more than thirty years later.
} 
accept mechanically-produced cigarettes, and the quality of manuallyproduced cigars, in particular, far surpassed that of mechanized ones. Apart from these technical and financial constraints, it seems to have been market deficiencies - the mismatch between supply and demand - that determined the rate of mechanization. Many of the tasks performed in the factory related to products for which there was little consumer demand. In addition, the market value of these products was inconsistent with the cost of production. This mismatch was so great that the main goal of the CAT was to eliminate it. The CAT tried to produce by both mechanical and manual methods new goods that corresponded better to consumers' tastes at a lower price. In a market where consumers' habits were essentially based on custom, changes had to be introduced slowly and with caution; in fact, only some of the new CAT products were accepted by the market.

This slow path towards modernization, influencing customers' habits whilst avoiding social disorder, was largely possible thanks to the firm's monopoly structure ${ }^{63}$ and to flexibility in the mode of production and the labour force. Nevertheless, during the period that the CAT was running the company, the production process was eventually mechanized, resulting in an 80 per cent reduction in personnel and the loss of production control by the workers, but also in a 7.5 per cent increase in productivity. In fact, the main strategy of the CAT was to modemize all areas of the tobacco industry: raw materials market, production, marketing, distribution, and so on. Regarding production and labour organization in the factories, the CAT adopted a two-pronged strategy: the mechanization of the workshops and the adaptation of the workforce to the number of cigarreras needed for the new mechanical order. To achieve this second aim, the CAT chose to abstain from firing cigarreras, and rather to limit the number of new hires and wait for this slow conversion to happen by itself. As a consequence, this process has passed into history as non-traumatic: there was no massive firing process and no violent workers' demonstrations. It has been suggested that the company displayed a paternalistic attitude due to the state connection and that the workers' passivity was due to lack of unionization at the time. The limited nature of this interpretation lies first in the fact that it takes the individual, rather than the family, as the unit of analysis and that it considers the worker in isolation from the family. The reduction in personnel due to the ending of a continuous hiring policy was indeed traumatic, in that it fundamentally destroyed the household economy model of the cigarreras. Second, this interpretation fails to ana-

63 Independent of the lease of the right to a state monopoly by a private company, the fiscal monopoly involves a distortion in the allocation of resources relative to the competitive model. In fact, when the management of a monopoly is nun by a private company, the subjection of the company to private law does not mean that the company develops a private activity; the main characteristic of the company activity is derived from the existence of the monopoly, which determines its dominant position in the market. 
lyse the relationship of capital and labour always in terms of conflict. ${ }^{64}$ In the short run, the workers benefited from this slow conversion, through the maintenance of a flexible labour organization.

The main family strategies of the cigarreras can be characterized by two major features: professional opportunities for family members and a trade-off between wages and time for household tasks. How did mechanization interconnect with these two main strategies in the consolidation of the male breadwinner family? Were these family strategies, representing mostly pre-industrial values and labour conditions determined by the gender of the workers, a marginal or an integral component in the process of industrialization in the tobacco factory at Seville?

\section{Mothers of workers}

During the nineteenth century, when the factory was hiring personnel on a regular basis, entry took two forms: through a relative (the family route) or as a result of a recommendation (the political route). While the second route was promptly eliminated by the CAT ${ }^{65}$ so far as the cigarreras were concerned, the influence of family ties on the recruitment of new workers was never eliminated, despite the changes in production conditions under CAT management.

\section{The manual apprenticeship system}

When production in the factory was manual and labour could be considered a quasi-fixed factor of production, the recruitment system was very convenient for the factory. The cigarreras provided their own apprenticeship system, based on the fact that the cigarreras brought their young daughters with them to the factory to tend the babies. The babies lay in cradles provided by the factory inside the workshops themselves. As cigarreras' daughters grew up in the workshop context, they learnt how to make cigarettes ${ }^{66}$ and how to be a cigarrera: mother and worker. The

${ }^{64}$ See P. Joyce, Work, Society and Politics (London, 1982), and M. Burawoy, The Politics of Production (London, 1985).

${ }_{65}$ The boss of the factory wrote the following to the director in Madrid in May 1922: "I could observe, with the biggest and most intimate protests, that all requests for personnel moves, leave of absence, promotions and the like are made by demanding recommendations from referees who are most of the time not related to the factory and unknown to me [...]. I am aware that all these workers are observing an old and well-established custom. However, I beg them to desist from these practices. No more policies based on influence, but rather on good behaviour." The political route was resurrected during the Civil War and post-war period because the factory employed ex-soldiers and collaborators of Franco.

${ }_{66}$ T. Hareven, Family Time and Industrial Time (Cambridge, 1982), p. 200, describes a similar case. In the Amoskeag Company, even though young workers did not actually enter factory work before the age of 16 , children were socialized to the work experience in the mill at an early age. Industrial labour became part of their life even before they actually worked. 
factory took advantage of this system, which provided a means by which to acquire a ready-made skilled workforce without having to invest in an apprenticeship programme requiring several years of training. ${ }^{67}$ These apprentices had only to achieve a certain proficiency in their tasks before they could be sent to any workshop. Factory rules - from 1834 right through to 1945 - provided that any apprentices taken on should be descendants of previous workers. ${ }^{68}$ In addition, the factory usually preferred the daughters of cigarreras because they were already familiar with the work ${ }^{69}$ and because it was easier to control the workforce if the whole family was dependent on the factory. The cigar-maker work culture fostered in the factory among the daughters of cigarreras also made them more attractive as potential employees.

\section{Family work and mechanization}

The family unit also profited from this system, because positions available in the factory were always reserved for daughters of the cigarreras. After

${ }^{67}$ M. Prus, "Mechanization and the Gender-Based Division of Labour in the U.S. Cigar Industry", Cambridge Journal of Economics, 14 (1990), pp. 63-79, maintains that the beginning of mechanization in the American tobacco industry was due to the interest of the employers in controlling production, thus depriving cigar-makers of the importance of their skills and eliminating the apprenticeshjps which had been a powerful weapon of these skilled workers.

Bs To reserve positions in the factories for the workers' relatives was very usual from the beginning of industrialization, in part because of the control exercised over the workers through this practice, and in part because of the role played by the family in the apprenticeship and recruiting system. Joyce, Work, Society and Politics, gives the example of Lancashire factories' bosses who obliged workers to bring their wives to the factory. Another example is the Amoskeag Company in Manchester, New England. Hareven, Family Time and Industrial Time, shows first that for the company the workers' families constituted an elastic reserve workforce adaptable to changing circumstances; second, that the factory saved on the apprenticeships because the workers were instructed by their relatives; third, that the workers developed a sociability in the factory to avoid conflicts; and finally, that the factory hired workers with a particular work culture learnt from childhood, and who therefore saw a job in the factory as the only possibility. Furthermore, the families profited from these practices because they found jobs for new family members coming into the city, and knew that the family would have sufficient employees in the factory to allow them to find lifetime employment in some capacity. The kinship system and these "labour rights" produced a comfortable atmosphere for the workers. For the economic origins of paternalism, see M. Huberman, “The Economic Origins of Patemalism: Lancashire Cotton Spinning in the First Half of the Nineteenth Century', Social Hisfory, 12 (1987), pp. 177-192, and for some objections of his theory see M. Rose, P. Taylor and M.J. Winstanley, "The Economic Origins of Paternalism: Some Objections", Social History, 14 (1989), pp. 89 103.

${ }^{69}$ The boss in Seville was not in favour of recruiting cigarreras' daughters, but company management and the state preferred this option to a social uproar: "Apprentices for the manual workshop? If you take account of my modest opinion, do not oblige me to hire apprentices for manual tasks; here and now, in this factory, it is better to talk about machines, mechanized workshops, apprentices for new tasks and cigarreras 'of the future' 
the CAT took over the factory, there was no recruitment of new labour for more than twenty years until new mechanized workshops were created. In fact, it was only during two very specific periods - 1909-1912 and 1922-1925 - that cigarreras' daughters were once again recruited to the factory after the new mechanized workshops had been introduced. Although the factory demanded no specific skills for staff in these mechanized workshops, it continued to hire daughters of cigarreras in preference to outsiders. The practice continued because, apart from maintaining manual production, it was considered the only means of avoiding strikes and a consequent paralysis of the workshops and production shortfall.

In fact, the recruitment of daughters was the main demand made by the cigarreras, because their labour strategies were almost exclusively focused on the factory. Cigarreras' acceptance of machines in order to maintain their household economy model is an example of how family strategies could be more important than craft strategies. The same women who wrecked the factory in $\mathbf{1 8 8 5}$ in response to a false rumour concerning the arrival of cigarette-making machines actually asked for such machines in 1909 , after a period of over twenty years during which there was no new recruitment of cigarreras to the factory. The management let it be known that the only way it could admit apprentices was through the introduction of the new mechanized workshops. In fact, the cigarreras changed strategies of behaviour in order to maintain the family labour model, even if it was to be destroyed in the long run. Another example is the way in which the cigarreras became literate. The CAT imposed certain restrictions on the admission of new workers: they had, for instance, to be between 16 and 30 years old and must be literate. This actually changed the literacy'rates among cigarreras before and after CAT. ${ }^{70}$ The factory's demand for literacy encouraged workers' families to educate their daughters. To send daughters to school was not a substitute for sending them to

with other manners and education; do not talk about the cigarreras' daughters trained by their mothers or grandmothers in the infamous tasks which ultimately manipulated their families, and introduced them to the customs and vices of older cigarreras": AFTS, Leg. 636. Exp. 12, Seville, 10 September 1909.

${ }^{70}$ The factory began to demand cigar-makers who knew how to read and write, so the cigarreras began to send their daughters to school: "[. . . I said before that the apprentices should not be older than 20 , and that all of them should know reading and writing. Since then, you see all the daughters of the cigarreras learning at the schools and colleges of Seville, as a result of the mothers' objective of seeing their daughters being recruited on the same terms as the first 24 apprentices used to implement smoothly and peacefully, the reforms needed to transform the factory from manual tasks to mechanical ones without excessive protests": AFTS, Leg. 636. Exp. 12, Seville, 10 September 1909. So literacy became a means by which to broaden professional opportunities. This accords with the thesis of C.E. Nuñez, La fuente de la riqueza. Educación y desarrollo económico en la España Contemporánea (Madrid, 1993) on differences in literacy by region and by sex in Spain, which shows that the literacy rates depended on the modification in labour opportunities that the parents decided for their children in response to the changes in the labour market. 
the factory, but a consequence of labour family strategies and factory labour demand plans.

\section{The gender change in family labour strategies}

While all cigarreras were descendants of tobacco factory workers, this was not until the 1930s the case with the tabaqueros. In 1925 recruitment of cigarreras ceased. At this point, the cigarreras' family labour strategy switched to the promotion of their sons instead of their daughters as factory workers and the proportion of tabaqueros descended from factory workers increased, although it remained less than that of the cigarreras. The reason is related to the kind of work performed by tabaqueros in the factory. It did not involve specific skills passing down from generation to generation within the family. Moreover, from 1936 onwards, the factory was obliged by the Franco regime to hire war veterans. These men probably occupied some jobs that would otherwise have been taken by cigarreras' sons.

The changes in the production process converted the nineteenth-century demand for a female workforce ${ }^{71}$ into a twentieth-century demand for a male one. During the nineteenth century it was cost-effective for the factory to take on cigarreras' daughters, but during the twentieth century such measures only continued as a means to avoid social protest and to smooth the way for the introduction of machinery. For the cigarreras' families, mechanization meant the end of their household economy system and a slow shift to the male breadwinner system, although even today most workers in the factory, both male and female, are descendants of former workers.

\section{Mothers and workers ${ }^{72}$}

Childcare and work outside the home were not incompatible with each other under the conditions obtaining in the industry. Even if being a mother was not crucial in explaining the female employment rates, as some authors have seen, ${ }^{73}$ particular conditions were needed to make these tasks compatible. It is necessary to study women in the labour force at the limits of what is possible given the options open to them.

\footnotetext{
"Under CAT management, it was possible in theory for cigarreras to bring only their very young babies with them to the workshops. This led to a loss in the transmission of skills, since in the former period older children - those over two years of age - were also in the factory caring for the little ones and learning the job.

72 This part of the article is mostly based on Gálvez-Muñoz, "Management, Labour and Gender".

${ }^{73}$ For J. Brenner and M. Ramblas, "Rethinking Women's Oppression”, New Left Review, 144 (1984), pp. 37-71, childcare and work outside the home were impossible to combine under the conditions of capitalist production.
} 


\section{The working day}

Under CAT management, the start of the cigarreras' working day continued to be flexible, as it had been under state management. They could start between 8 and 10 o'clock in the morning, but - as previously - it was quite common to come in later. In fact, one of the reasons underlying the cigarreras' strike in 1896 was the inconvenience caused by the CAT's new rule prohibiting arrival after 11 o'clock. This could be difficult because by then the women had to finish household tasks such as "to dress their children, cook, clean their houses and perform other maternal duties". ${ }^{74}$ The maintenance of a flexible working day was also the reason why the cigarreras opposed the introduction of the eight-hour working day, ${ }^{75}$ contrary to union demands. ${ }^{76}$ After the introduction of the eight-hour day, in October 1919, the tobacco factory at Seville allowed the cigarreras to come in between 8 and 10 o'clock in the morning. Nevertheless, it continued to be usual for some cigarreras to arrive at the factory after 10 o'clock." In fact, flexible hours and the frequent tolerance of nonattendance by cigarreras constituted a tacit recognition of the domestic role of women. ${ }^{78}$ At the same time, this flexibility responded to the necessities derived from the general organization of production. Because the cigarreras worked on a piece-work system, ${ }^{79}$ hours were arranged on the

\footnotetext{
${ }^{74}$ The Baluarte of 28 January 1896, quoted in Baena Luque, Las cigarreras sevillanas, p. 76.
}

75 The Real Decreto of 23 April 1919 introduced the eight-hour working day. The CAT introduced the eight-hour working day from October, 1919: "[...] According to this law that [...] has harmonized the uses and conditions of each town with the familial necessities of thousands of working mothers, wives and daughters [.. . ] the daily work time has been made more human in terms of average working time per day since this does not exceed 8 hours [...] according to the opinion of maestras and cigar makers thus reforming the intemal rules of the factory [...]": AFTS Correspondencia, Leg. 19, 23 September 1919.

${ }^{76}$ Cigarreras opposed to the eight-hour working day went on strike in December 1919 and January 1920. The law imposed a fixed working time and cigarreras considered they lost money because they used to arrive later in the moming. They asked for an increase in piece-rates of 50 per cent. The conflict ended when the company increaseat the piece-rate to 25 per cent, even though it felt 15 per cent would have been enough: AFTS, Correspondencia, 22 January 1920.

"In January 1922, Seville suffered a very severe flu epidemic which affected a lot of factory workers. During this time, the factory was running at a loss, and the directors of the company issued the following rule: "To balance this deficit [...], some measures will be established in order to improve punctuality in the factory: first, admission to the Factory ends at 11 , which increases the time entrance band by one hour with respect to the official one. Despite the inconvenience of this rule to the cigar-maker, it will increase cigarette production by at least 10 per cent [...." $]^{m}$ : AFTS, Correspondencia, Leg. 21, 25 January 1922.

78 Toleration of non-attendance among cigarreras in order to take care of other members of the family was reported in the 1927 rules, article 8. They received the fixed part of their wages for an maximum of eight days. This article did not apply to tabaqueros.

79 The pure piece-work system ended in 1917 , when workers started to receive a fixed portion of their daily wage. 
basis of production plans, individual productivity ${ }^{80}$ and the trade-off between wages and time for the household economy. The fact that many cigarreras came into work after $11 \mathrm{o}^{\prime}$ clock in the morning meant that, under conditions of manual production, the cigarrera was in charge of her own factory working time. This flexibility was transformed by mechanization. The introduction of mechanized workshops divided the cigarreras working in the factory into two categories: young ones who arrived punctually to work in the mechanized workshop and older ones who were less punctual in the manual workshops. ${ }^{81}$ Once mechanical production became the norm, the manual workshops became a place for cigarreras who could not be fired and a precaution against a possible change in consumption patterns. Mechanization spelt the disappearance of the cigarrera as a skilled worker in control of her own factory working time. In spite of this, starting times and attendance continued to be flexible for many of them, a policy of tolerance reflecting a company strategy of accommodating a manual system to a mechanical one while avoiding unpopular adjustments for existing staff.

\section{A culture of absenteeism ${ }^{82}$}

The flexible pattern of attendance and persistent absenteeism in the factory during the industrialization period illustrates the interaction between the family and the market better than the flexible daily use of time. Sometimes this was because of a collusion between the flexibility needed by the company ${ }^{83}$ and the flexible use of time needed by the cigarreras to accomplish

${ }^{30}$ Among the cigarreras, there was a high degree of solidarity and mutual support. One cigarrera (C.M.A., interviewed in March 1994) said that she was more productive than her sister and used to help her to reach the quota every day. P.A. Cooper, Once a Cigar Maker: Men, Women and Work Culture in American Cigar Factories, 1910-1919 (Urbana, 1987), on work culture between men and women in the American tobacco industry, has also encountered this solidarity among women who worked in groups: "Women created a bank so that they could share tobacco with each other out of the foreman's sight and help everyone meet quota, which reflected a collective, rather than individual, approach to shopfloor discipline" (p. 321).

81 This double use of time was sanctioned in the 1927 rules, when the company knew that the end of the manual workshops was only a question of few years. Article 40 of the 1927 rules established that: "The official number of working hours at the factory will be established as 8 , which can be adapted to any special personal and town circumstances. In the manual workshops, considering that their members are mostly aged, the time of entrance to the workshops can be more flexible but, given that the exit time is fixed, they will work less than the 8 hours when they arrive later."

\$2 Because cigarreras' absences were a real problem for management, as reflected in company records, it is possible to use the term absenteeism when referring to the cigarreras' absences.

*3 Through the study of the financial aspects of the companies, it is possible to know whether or not companies profited from non-attendance. See T. Barmby, C.D. Orme and J. Treble, "Worker Absenteeism: An Analysis Using Microdata", Discussion paper series, Centre for Economic Policy Research (London, 1990), and idem, "Worker Absence Histo- 
their household tasks, and sometimes the practice was seen as the lesser of two evils: preferable to the alternative of firing workers and creating social uproar. The continued toleration of these practices by the factory, even after the workshops were mechanized, has to be understood from within a monopoly system and in relation to a company strategy derived from the flexibility needed in this transition period. The maintenance of these practices related to the family has to be understood within this historical context and through a gender analysis. In past centuries, household work involved a greater number of tasks than it does nowadays and, in the context of the living conditions of working-class families, absenteeism could be understood as enabling the part-time running of the household. ${ }^{84}$

The cigarreras maintained a level of non-attendance during this period equivalent to around 20 per cent of total attendance at the beginning of the period of CAT management, 10 per cent in the years following World War I, and nearly 30 per cent in the 1930s. This variation was mostly in response to the factory's demand for production. The collusion between company strategies and custom, motivated by both labour and family considerations, needs some explanation. During the nineteenth century, increasing consumption of cigars and cigarettes provoked continual recruitment of personnel, mostly descendants of cigarreras. Cigar-making was a semi-autonomous profession. The women worked on a piece-work system and had to bring their own tools to the factory. ${ }^{85}$ No control was exercised over attendance in the workplace. ${ }^{86}$ This production context, together with the state monopoly structure of the factory and the fact that the skilled workers were women who needed time for household tasks, encouraged the development of a culture of absenteeism. In contrast to

ries: A Panel Data Study", Working paper, School of Accounting Banking and Economics (University of Wales, Bangor, 1994), who have demonstrated the potential importance of considering the financial aspects of the firm and attendance control in explaining persistent absenteeism.

a Nevertheless, part-time jobs continued to be performed by women. In fact, studies of household labour beginning in the 1910s and continuing through to the 1970 s show that the amount of time a full-time housewife devoted to her housework remained virtually unchanged over a 50-year period, despite dramatic changes in household technology (see N. Folbre and B. Wagman, "Counting Housework: New Estimates of Real Product in the United States. 1800-1860", The Journal of Economic History, 53 (1993), pp. 275-288). J. Schor, The Overworked American. The Unexpected Decline of Leisure (New York, 1991), p. 8, explains that over time, new responsibilities were created, such as the need to pay more attention to the education of children and to personal care.

ss The 1835 rules said that: "[... .] workers should carry with them chairs, scissors [.. .]: Obligaciones y Facultades del Superintendente, 1835. AHFT (Archivo histórico fábrica de Sevilla), Expedientes generales, Leg. 628.

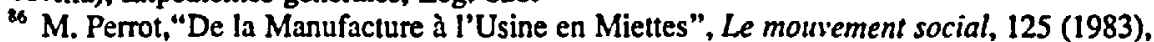
pp. 3-12, esp. p. 5. The piece-work system did not demand a continuous control as did work in the textile factories because piece-work labourers enjoyed a flexible use of time. The disciplinary crisis at the beginning of the twentieth century was in part a consequence of the application of a "textile" discipline to other industries. 
the cigarreras' flexible use of time, the tabaqueros' working day conformed to conventional standard working hours. Cigarreras had different patterns of attendance from those of tabaqueros not only because they were female workers but also because of their working conditions, given the remuneration system. ${ }^{87}$ Tabaqueros did not have this flexible use of time but enjoyed higher wages than the cigarreras. The organization of the factory recognized the role of men as breadwinners and the domestic role of women, even if the cigarreras' jobs were actually the most important to the household economy. The firm divided its profits amongst its workers as required by society, compensating men in terms of money to perform the breadwinner role and women in the terms of time to perform "their" ${ }^{88}$ household tasks. As a result of mechanization, men and women eventually switched importance in the factory's labour plans ${ }^{89}$ and in their contribution to family incomes.

87 For example, when comparing the Spanish tobacco industry with its American counterpart, in which the skilled cigar-makers were men, the influence of the labour conditions on the different use of time between women and men becomes more apparent. Cooper, Once a Cigar Maker, has shown how male tobacco workers (unionists) in the US, because of their level of skill, had a higher piece-rate and enjoyed greater freedom in their use of time than women using moulds and machinery (team work). W.D. Evans, "Effects of Mechanization in Cigar Manufacture', Monthly Labor Review, Report No. B-4 (1938), pp. 1-21, in his report on the American tobacco industry, writes for the Department of Labour: "[. . . ] hours of labour in factories making cigars by hand especially before the introduction of machines, were in general somewhat informal [... . many cigar-factory employees do not work all the hours the factory is open and work afforded. The work is so largely individual in many factories that the coming and going of employees does not interfere materially with the work of others - this information is related to 1911-12 [... ]" (pp. 1819). The remuneration system is very important in explaining the absence behaviour of workers. J. Treble, "The Wages Book of Garesfield Butepit, County Durham: Data Description and Summary Statistics, June 1890 to June 1892" (Labour Economics Unit, Research Papers 90/2, University of Hull, 1990), a study of the Durham mines workers, established the way in which workers were remunerated as an important determinant of absenteeism: as important as labour conditions in the different areas of work in the mines, such as humidity, depth, etc.

${ }^{88}$ Their house or their tasks were the terms under which women with no market occupation are recorded in twentieth-century Spanish censuses prior to the advent of democracy.

29 Control of production in the workshop was no longer exercised by the cigarreras but by the mechanics. Comparing the models of the evolution of the sexual division of labour in the Spanish tobacco factories and those in the United States (see Prus, "Mechanization and the Gender-Based Division of Labour"), it is possible to observe that the homogenization of both models was only accomplished with complete mechanization. In the US, the skilled workers were men, and women joined the tobacco industry at the end of the nineteenth century, parallel to the application of the first semi-mechanical techniques. When factories became fully mechanized, the women took over the men's posts. As in the Spanish case, workers making cigars mechanically lost the importance in the production process possessed by the manual cigar-makers. In both tobacco industries, the new key job in the workshops was that of the mechanic, and in both this was the province of men. While in Spain control over production passed with the mechanization from women to men, in the US - even though there was a switch in duties - the transition was man to man. See Gálvez-Muñoz, “Management, Labour and Gender". 


\section{Modernization plans and flexible use of time}

The flexibility required during this period and the maintenance of a skilled but frequently absent workforce was a second-best strategy, employed due to the impossibility of eliminating the labour surplus created when the cigarreras were replaced by machines but social, financial, ${ }^{90}$ technical and market constraints prevented their dismissal. Flexibility was needed, on the one hand, to match tobacco supply to demand and, on the other, to begin the process of mechanization and modify the workforce in a way which would avoid social unrest. It was achieved first because the monopoly system permitted a slower and more secure transition; and second because the workers' flexible use of time provided an available skilled labour force when it was needed.

The state and the firm's monopolistic structure played an essential role in allowing the mechanization of production to coexist with the cigarreras' absenteeism. Although the state could be expected to be more interested in maintaining social stability (more especially, in this case, because of the importance of tobacco factories to their various local labour markets), it was the monopoly structure of the firm more than the interventionist power of the state that explains the caution employed in the implementation of the CAT's two main strategies: mechanization and the reduction of the labour force. On one hand, the monopolistic character of the business permitted price control, while also pursuing a cost-based pricing policy. On the other hand, apart from the direct effect of public patemalism on the rise of absenteeism rates, ${ }^{91}$ the fact that the tobacco factories were real instruments of political clientelism led local forces to express strong opposition to any mass firing policies as a consequence of the investments in modern technological equipment.

The toleration of absenteeism in the tobacco factory at Seville and the plans to rationalize production could coexist due to the following factors. First, absenteeism did not affect relative wage costs under a piece-work system of remuneration. Second, the CAT's need for flexibility to meet the demand for tobacco during the mechanization process was reinforced by the fact that tobacco was a perishable product ruined by long storage. Flexible production to solve the mismatch between supply and demand

90 The high rent that the CAT had to pay to the state was due to the importance of fiscal monopolies, and especially the tobacco monopoly, to the Spanish Treasury. It has to be related to the insufficiency of tax resources and Spanish backwardness in refusing modem tax systems. About the fiscal monopolies, see F. Comín, “La empresa pública en la España contemporánea: formas históricas de organización y gestión", in Comín, La empresa en la historia de España, pp. 349-367.

${ }^{91}$ G. Esping-Andersen, "Decommodification and Work Absences in the Welfare State", Working paper, IUE, no. 367 (Florence, 1988), studying absenteeism in the Scandinavian countries, has demonstrated that the state promoted non-attendance more as an employer than as a legislator. 
inherited from state management also required a flexible labour force. For this reason, during the first decades of CAT management, before the introduction of semi-mechanical and mechanized workshops, the firm implemented a labour hoarding strategy. ${ }^{22}$ The maintenance of more cigarreras than production needs required helped to lower the hiring and firing costs if the market changed. Because of the cigarreras' culture of absenteeism, it was necessary to have 15-20 per cent more cigar-makers in the workshop in order to maintain production. The specific skills of cigar-makers and the existence of highly substitutable workshops eased internal labour mobility, mitigating the effects of absenteeism on production. This system also permitted the coexistence of absenteeism and mechanized workshops where the investment in technology (in capital) required a continuous flow of personnel. These practices became an alternative to firing workers since, at the same time, the company did not exploit its right to dismiss 25 per cent of the labour force. Indeed, the firm's inaction in this respect constituted a conscious policy of avoiding social unrest by transferring all responsibility to the worker. This gradual transition to industrialism would have been impossible with a male labour force.

\section{The market, production plans and absenteeism}

The CAT used incentives to attract cigarreras to the factory in order to tailor the number of workers to production needs in response to market changes and production plans. For instance, from 1917 onwards, the firm added an attendance incentive component to the cigarreras' pay in order to solve the problem of insufficient tobacco production. As a matter of fact, the lowest absenteeism rates occur from this date through to 1925. The policy of freezing new recruitment after 1887 was reasonable as long as labour was being replaced by machines. However, the number of employees in the factories dropped considerably over this period. The

92 The concept of labour hoarding comprised the company strategy applied during the economic recessions, mostly among workers with specific skills. This strategy consists of maintaining more workers than production needs rather than firing them, because of the transaction costs that the company has to suffer, not only for the fired workers but more for the cost of the substitution of these workers on the labour market when the economic situation changes. This idea has its origins in the variability and uncertainty of modem economies, and in the concept of work as a quasi-fixed factor of production. This implies that managers have an incentive to consider workers as capital when they have taken on part of the training of the worker. The first person to sustain the idea of work as a quasifixed factor of production was W.Y. Oi, "Labor as a Quasi-Fixed Factor", Journal of Political Economy, 70 (1962), pp. 538-555. The Marxist concept of excess army could not be used in this model. This concept implies the existence of an excess labour population which worked as crowbar for capitalist accumulation: see H. Brayerman, Labor and Monopoly Capital (New York, 1974). Nevertheless, this concept saw the worker as exploited, while the cigarreras profited in terms of time from this company strategy, which was in itself mostly an adaptation of the earlier situation. 
beginning of the attendance incentive payments in 1917 changed the remuneration system, introducing a mixed model of payment consisting of a fixed part and a variable part depending on individual production. ${ }^{33}$ At the same time, the new payments acted as an incentive to attendance in the workplace because workers received them only if they turned up at work. As a result, the opportunity cost of absenteeism to the household economy was now higher. By contrast, during the 1930s the factory encouraged non-attendance by the cigarreras by allowing sick leave regardless of whether cigarreras were really ill. The introduction of apprenticeships in the 1920s and the mechanization of the majority of the workshops resulted in an excess of workers, which also affected the mechanized workshops. ${ }^{94}$ Until this time, the manual workshops with skilled workers had been maintained to allow for any shift in consumer preference towards manually produced cigars and cigarettes. This meant that some new workers could be trained in manual techniques. However, the definitive acceptance of machine-made cigars and cigarettes made the manual workshops and their workers practically redundant. The average daily wage of a cigar-maker in 1930 amounted to 7.17 Pts. Sick leave reduced this to 5 Pts per day. Since workers could not be dismissed because of state pressure, absence brought double benefits to management: it reduced average wages and limited the excess production of tobacco, which would otherwise have had to be stored and possibly thrown away. Doctors gave unlimited leave of absence for illness. Sick leave gave the cigarreras money and time. In fact, in 1933 when the cigarreras' and tabaqueros' union denounced the doctors for negligence in granting leave of absence, only two women obeyed the union and signed the protest, although the cigarreras constituted 80 per cent of union members. As in the case of the eight-hour working day, they defended family strategies against union strategies. ${ }^{95}$

A change in the nature of the absenteeism occurred when there was a break in the previously direct link between time needs for household tasks and job attendance. When the CAT started to subsidize cigarreras' absenteeism through sick leave (because it could not fire them), the company also took control of cigarreras' absences. The company was expecting the

93 The fixed part was 0.25 Pts a day when it was established in 1917. It was raised to 0.5 Pts in 1918; to 1 Pts in 1919; to 2.5 Pts in 1930; and to 3 Pts in 1933.

94 In an inspection of the workshops made on 18 May 1931, the administration made a list of cigarreras in the workshops and cigarreras taking any kind of leave. For example, in the mechanized cigarette workshops, it was calculated that the number of workers needed for production was 54, but there were 65 on the list. These 11 cigarreras were an excess of supply which smooth the functioning of the workshop when other cigar-makers did not attend. If the number in attendance exceeded 54 they were employed in other workshops: AFTS, Leg. 917.

9s In 1919, the cigarreras' opposition to the eight-hour working day could be understood as an opposition to a general working-class demand. But on this occasion, the opposition is specifically to the cigarreras' and tabaqueros' union. The Seville section, NICOT, denounced the doctors because they refused to become members of the union. 
government to pass a compulsory retirement law for tobacco workers in order to rid itself of the excess workers who could not be fired. When legislation was passed introducing a compulsory retirement age of 67 for CAT employees, the necessary adjustment in staff size was finally made. The number of workers in the company at last approximated to the optimal number required for mechanized production. It was only after the retirement law for the tobacco workers came into effect that the age of workers in the factory was limited to $67 .{ }^{96}$ This law was mainly a necessary instrument to adjust the size of the staff to the new mechanical order.

The flexible use of time and the gender of its workers formed an integral component of the industrialization process in the tobacco factory. The maintenance of the female labour force's opportunities was closely related to the gradual way in which the company imposed industrialization. The gender of workers not only permitted this flexibility, but also helped to make the transition less traumatic. Precisely because women were not supposed to be breadwinners, a labour adjustment involving as much as 80 per cent of the workforce in a factory linked with the public administration would have been more difficult and violent with male workers rather than female.

\section{CONCLUSIONS}

Through the analysis of a wide range of exogenous factors, this essay shows the necessity of employing a more historical approach to explain breadwinner patterns. Nevertheless, although the local labour market, regional economy, company labour policy, institutions, laws and customs all played a fundamental role, both patriarchy and capitalism continued to provide strong explanations for the consolidation of the male breadwinner family. On one hand, the study of cigarreras' labour and household models demonstrates the strong explanatory power of patriarchy. In this historical context, a breadwinner-wife was possible but a house-husband was not. In fact, the model of the cigarrera was only possible because of the special working conditions which allowed these women to bring their babies to the factory, to enjoy a flexible use of time and to control the apprenticeship system, and because of the high rates of unemployment in

* This law was promulgated on 2 July 1936. But the law came into force only when the Civil War ended and the management of all Spanish tobacco factories was reunified. That retirement was beneficial for the workers and for the company is shown by the fact that the company managers and the tobacco workers' union jointly petitioned the government for it. The company expressed itself in these terms: "This workforce is mainly aged and has imposed a constraint on technical development. We have compensated for this economically by intensive production and redistributing work spaces in order to reduce pressure on some workshops, as well as by better discipline and supervision [...] Socially, we have observed moral responsibility towards those workers who have devoted all their lives to the factory": quoted in Valdés Chápuli, La Fábrica de Tabacos de Alicante, p. 73. 
the local labour market. On the other hand, the industrialization of the Spanish tobacco monopoly spelt a change in the cigarreras' family economy system at three different levels: first, as a result of the reduction in female staff employed by the CAT, the number of families associated with the system declined. As a matter of fact, there was a reduction in the percentage of wives occupied and an identification of the female workforce with unskilled and temporary workers in the Seville labour market. Second, the number of cigarreras per family decreased. Following the freeze on recruitment to the workshops, only two cohorts of female descendants were able to enter the factory during the period studied. The result was a gender change in the composition of the factory's workforce and in the family labour supply. After mechanization, the company stopped hiring female tobacco workers but increased its demand for male workers. As a consequence, the family labour supply changed from a female to a male workforce by promoting sons as the most eligible candidates for factory jobs. As a consequence of industrialization, the cigarreras' family model changed to a male breadwinner family system. And third, parallel to the de-skilling process experienced by the cigarreras, the labour supply model (or the transmission of jobs from one generation to the next) ceased to be a necessity imposed by the family apprenticeship system, and became a concession by the company in response to worker pressure. In addition, there was a breakdown in the transmission of skills from mothers to daughters, resulting in the end of this skilled female labour model.

This article has tried to demonstrate the interactive relationship between the family and the market. The joint analysis of company strategies and family strategies during the industrialization process at the tobacco factory of Seville shows how the cigarreras' family strategies were an integral component in this process, apparently helping to render the transition to industrial capitalism less traumatic, even while destroying the traditional cigarreras' family economy model. The mechanization of the factory under CAT management was gradual but effective, thanks to the firm's monopoly structure and the flexible organization of production. This process was interconnected in a different way with the two main family strategies. If the flexible use of time needed for the running of the family unit colluded with the labour flexibility needed by the company during this transitional period, the maintenance of hereditary hiring policies was due more to political than to economic considerations. The recruitment of new apprentices coincided with the start of the mechanized workshops. Even if the company did not benefit economically from this practice since the apprenticeship system was no longer essential to mechanical production, its use of apprenticeship may be explained first by the fact that it helped the firm to avoid social unrest and second on the basis that it helped a group of workers to accept the machines which they had traditionally opposed. 
Table 5. Sample of cigarreras census bias

(730 households in Triana, census 1924)

\begin{tabular}{ll}
\hline In census & 23 \\
Total & 87 \\
$\%$ in the census & $26.4 \%$ \\
\hline
\end{tabular}

Table 6. Average income share, 1924

\begin{tabular}{|c|c|c|c|c|}
\hline Type & Code & All cigarreras & One cigarrera & Rest \\
\hline \multirow{2}{*}{$\begin{array}{l}\text { Families with at least one } \\
\text { cigarrera }\end{array}$} & 1 & $55.7 \%$ & $68.5 \%$ & $31.5 \%$ \\
\hline & & Householder & & Rest \\
\hline $\begin{array}{l}\text { Householder: female } \\
\text { Householder: day labourer } \\
\text { Householder: semi-skilled } \\
\text { and skilled industrial }\end{array}$ & $\begin{array}{l}2 \\
3 \\
4\end{array}$ & $\begin{array}{r}3.1 \% \\
62.6 \% \\
63.9 \%\end{array}$ & & $\begin{array}{l}96.9 \% \\
37.4 \% \\
36.1 \%\end{array}$ \\
\hline
\end{tabular}

Finally, this paper calls for the use of the same approach in analysing female and male labour behaviour. Since the interrelationship between the family and the market is a gendered construct, men and women should both be studied in the family and in the market. Scholars should avoid explaining the working life of women solely in terms of gender, identifying women with unskilled work, and explaining the working life of men solely in terms of labour, identifying men as the breadwinners. General theorizations need to be reconsidered in favour of a more historical approach. 